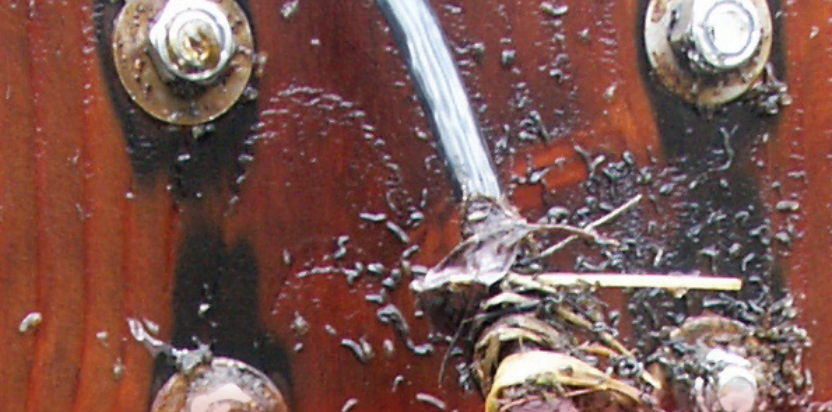

Prepared in cooperation with the Golorado Water Conservation Board 20

Y Evaluation of the Acoustic Doppler Velocity Meter for 2 Computation of Discharge Recordis at Three Sites in Colorado, 2004-2005

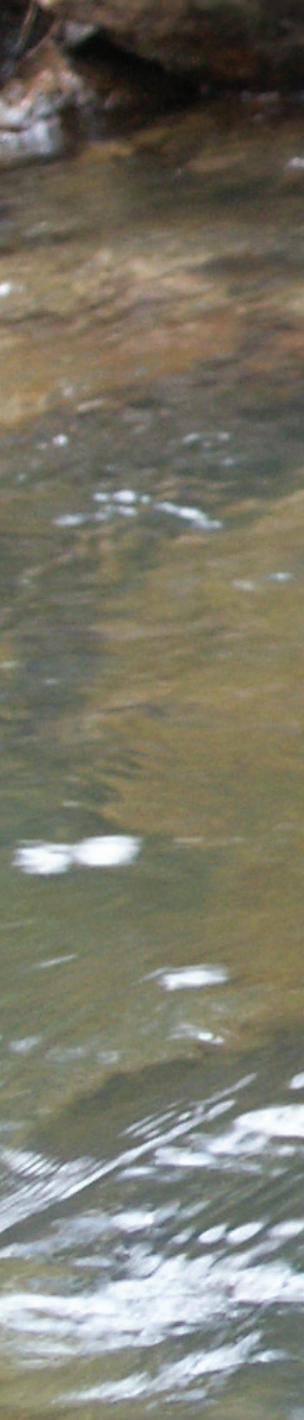

Scientific Investigations Report 2007-5236
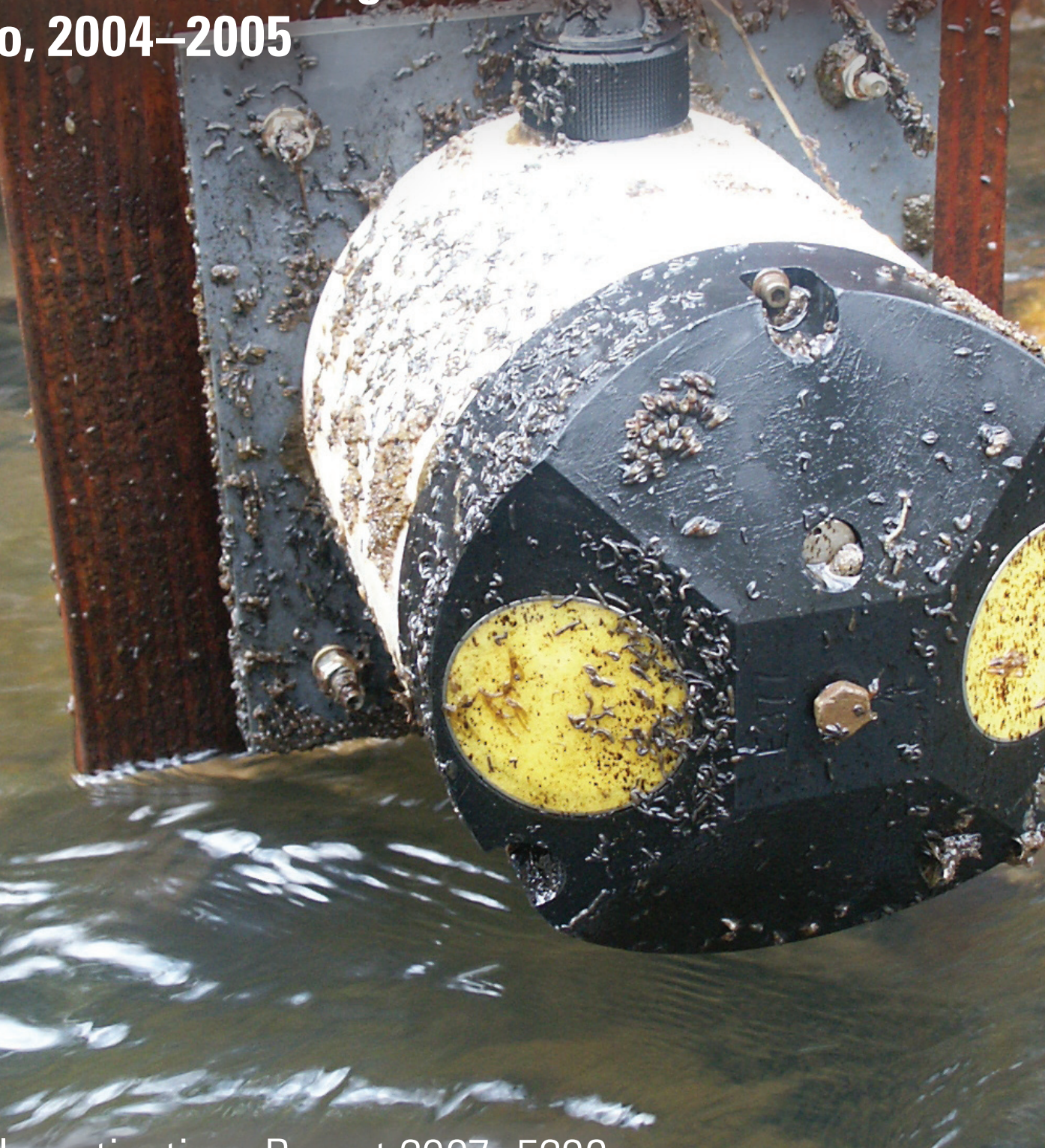

\title{
Scientific
}
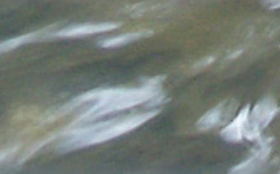

U.S. Department of the Interior U.S. Geological Survey 



\section{Evaluation of the Acoustic Doppler Velocity Meter for Computation of Discharge Records at Three Sites in Colorado, 2004-2005}

By Michael R. Stevens, Paul Diaz, and Dennis E. Smits

Prepared in cooperation with the Colorado Water Conservation Board

Scientific Investigations Report 2007-5236 


\title{
U.S. Department of the Interior DIRK KEMPTHORNE, Secretary
}

\author{
U.S. Geological Survey \\ Mark D. Myers, Director
}

U.S. Geological Survey, Reston, Virginia: 2008

\author{
About USGS Products \\ For product and ordering information: \\ World Wide Web: http://www.usgs.gov/pubprod \\ Telephone: 1-888-ASK-USGS \\ living resources, natural hazards, and the environment: \\ World Wide Web: http://www.usgs.gov \\ Telephone: 1-888-ASK-USGS \\ About this Product \\ For more information concerning this publication, contact: \\ Team Chief Scientist, USGS Colorado Water Science Center \\ Box 25046 \\ Denver Federal Center, MS 415 \\ Denver, C0 80225-0046 \\ (303) 236-4882 \\ Or visit the Colorado Water Science Center Web site at: \\ http://co.water.usgs.gov/ \\ This publication is available online at: \\ http://pubs.usgs.gov/sir/2007/5236/
}

For more information on the USGS - the Federal source for science about the Earth, its natural and

Suggested Citation:

Stevens, M.R., Diaz, Paul, and Smits, D.E., 2008, Evaluation of the acoustic Doppler velocity meter for computation of discharge records at three sites in Colorado, 2004-2005: U.S. Geological Survey Scientific Investigations Report 2007-5236, 24 p.

Any use of trade, product, or firm names is for descriptive purposes only and does not imply endorsement by the U.S. Government.

Although this report is in the public domain, permission must be secured from the individual copyright owners to reproduce any copyrighted materials contained within this report. 


\section{Contents}

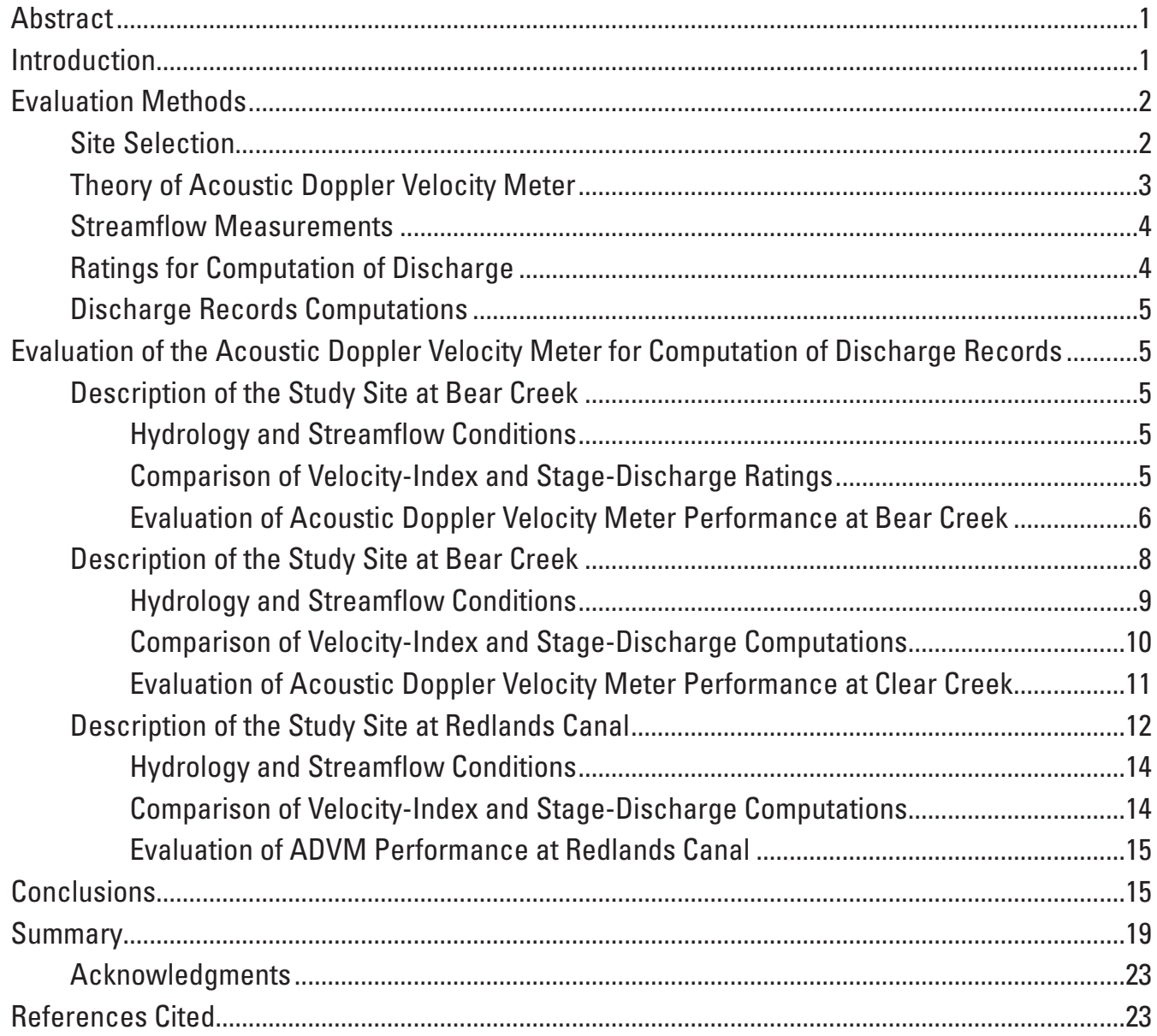

\section{Figures}

1. Map showing location of sites where acoustic Doppler velocity meters were evaluated in Colorado, 2004-2005...

2. Reference cross section at Clear Creek showing how an acoustic Doppler velocity meter (ADVM) samples the average velocity

3. Comparison of mean daily discharge produced by conventional methods (computed) and by acoustic Doppler velocity meter (ADVM), Bear Creek at Morrison, Colorado .....6

4. Velocity-index ratings for Bear Creek at Morrison, Colorado: $(A)$ rating 1, velocities measured September to December 2004, and (B) Rating 2, velocities measured March through August 2005

5. Comparison of computed and acoustic Doppler velocity meter (ADVM) discharge, Bear Creek at Morrison, Colorado........................................................................................

6. Percentage of difference between daily mean discharge determined by acoustic Doppler velocity meter and that computed by the stage/discharge relation, Bear Creek at Morrison, Colorado. 
7. Cumulative percentage of absolute difference in relation to absolute percentage of difference between acoustic Doppler velocity meter (ADVM) and computed discharge, Bear Creek at Morrison, Colorado.

8. Response of the acoustic Doppler velocity meter during under-ice conditions, Bear Creek at Morrison, Colorado, November 11 to December 12, 2004.

9. Comparison of mean daily discharge produced by conventional methods (computed) and by acoustic Doppler velocity meter (ADVM), West Fork Clear Creek near Empire, Colorado.

10. Velocity-index ratings for Clear Creek above West Fork Clear Creek near Empire, Colorado

11. Comparison of computed and acoustic Doppler velocity meter (ADVM) stage discharge, Clear Creek near Empire, Colorado.

12. Percentage of difference between daily mean discharge determined by acoustic Doppler velocity meter and those computed by the stage/discharge relation, Clear Creek near Empire, Colorado.

13. Acoustic Doppler velocity meter (ADVM) velocity and gage-height values at Clear Creek above West Fork Clear Creek, near Empire, Colorado, mid-July through August 2005 indicating hysteresis at velocities of about 1 to 2 feet per second 15

14. Percentage of difference between daily mean discharge determined by acoustic Doppler velocity meter (ADVM) and those computed by the stage/discharge relation at Clear Creek above West Fork Clear Creek, near Empire, Colorado, and the percentage of difference between daily mean discharge computed by stage/discharge relation at Clear Creek above Georgetown Lake and the daily mean discharge computed by stage/discharge relation at Clear Creek above West Fork Clear Creek, near Empire, Colorado.

15. Cumulative percentage of absolute difference compared to absolute percentage of difference between acoustic Doppler velocity meter (ADVM) and computed discharge, Clear Creek above West Fork Clear Creek, near Empire, Colorado

16. Response of the acoustic Doppler velocity meter to runoff conditions April 27to May 19, 2005, Clear Creek above West Fork Clear Creek, near Empire, Colorado ..........18

17. Comparison of mean daily discharge produced by conventional methods (computed) and by acoustic Doppler velocity meter (ADVM), Redlands Canal near Grand Junction, Colorado. Breaks in the graphs represent periods of no data.

18. Velocity-index ratings for Redlands Canal near Grand Junction, Colorado:

(A) rating 1, velocities measured 2004, and (B) rating 2, velocities measured 2005........20

19. Comparison of computed and acoustic Doppler velocity meter (ADVM) discharge, Redlands Canal near Grand Junction, Colorado.

20. Percentage of difference between daily mean discharge determined by acoustic Doppler velocity meter and those computed by the stage/discharge relation, Redlands Canal near Grand Junction, Colorado.

21. Cumulative percentage of absolute difference compared to absolute percentage difference between acoustic Doppler velocity meter (ADVM) and computed discharge, Redlands Canal near Grand Junction, Colorado 
Conversion Factors, Datum, and Acronyms

\begin{tabular}{|c|c|c|}
\hline Multiply & By & To obtain \\
\hline \multicolumn{3}{|c|}{ Length } \\
\hline foot (ft) & 0.3048 & meter $(\mathrm{m})$ \\
\hline mile (mi) & 1.609 & kilometer $(\mathrm{km})$ \\
\hline \multicolumn{3}{|c|}{ Area } \\
\hline square foot $\left(\mathrm{ft}^{2}\right)$ & 0.09290 & square meter $\left(\mathrm{m}^{2}\right)$ \\
\hline \multicolumn{3}{|c|}{ Volume } \\
\hline cubic foot $\left(\mathrm{ft}^{3}\right)$ & 0.02832 & cubic meter $\left(\mathrm{m}^{3}\right)$ \\
\hline \multicolumn{3}{|c|}{ Flow rate } \\
\hline foot per second $(\mathrm{ft} / \mathrm{s})$ & 0.3048 & meter per second $(\mathrm{m} / \mathrm{s})$ \\
\hline cubic foot per second $\left(\mathrm{ft}^{3} / \mathrm{s}\right)$ & 0.02832 & cubic meter per second $\left(\mathrm{m}^{3} / \mathrm{s}\right)$ \\
\hline
\end{tabular}

Temperature in degrees Celsius $\left({ }^{\circ} \mathrm{C}\right)$ may be converted to degrees Fahrenheit $\left({ }^{\circ} \mathrm{F}\right)$ as follows:

${ }^{\circ} \mathrm{F}=\left(1.8 \mathrm{x}^{\circ} \mathrm{C}\right)+32$

Vertical coordinate information is referenced to the North American Vertical Datum of 1988 (NAVD 88).

Horizontal coordinate information is referenced to the North American Datum of 1983 (NAD 83).

Altitude, as used in this report, refers to distance above the vertical datum.

Water year: A water year is the 12-mnth period from October 1 through September 30. It is designated by the calendar year in which it ends.

Acronyms used in this report:

ADAPS Automated Data Processing System

ADCP Acoustic Doppler Current Profiler

CWCB Colorado Water Conservation Board

DWR Division of Water Resources

USGS U.S. Geological Survey 



\title{
Evaluation of the Acoustic Doppler Velocity Meter for Computation of Discharge Records at Three Sites in Colorado, 2004-2005
}

\author{
By Michael R. Stevens, Paul Diaz, and Dennis E. Smits
}

\section{Abstract}

The U.S. Geological Survey (USGS), in cooperation with the Colorado Water Conservation Board, conducted a study in 2004-2005 at three sites in Colorado: Bear Creek at Morrison, Clear Creek near Empire, and Redlands Canal near Grand Junction. The study was done to evaluate acoustic Doppler velocity meter (ADVM) technology in different hydrologic settings that are characteristic of many Colorado streamflowgaging sites. ADVMs have been tested and used extensively in many parts of the United States by USGS but not in Colorado where relatively small, shallow, clear, coarse-bed streams that ice up in the winter may affect the ADVM suitability.

In this study, ADVM instrumentation was successfully used and discharge computations compared favorably, generally within 5 to 10 percent, with conventional USGS stage/ discharge methods at the three Colorado sites. However, two factors, encountered in this study, may adversely affect the use of ADVM technology in Colorado. First, for some streams, the depth required (about 1.5 feet for a side-looking instrument) cannot be met during low-flow periods of the year. Second, cold temperatures and freezing-thawing cycles can produce ice effects that could prevent collection of usable ADVM (and stage) data.

Some Colorado streamflow-gaging sites have conditions where ADVM measurements may enhance accuracy or ease of computation. Variable backwater from tributary inflow, beaver dams, ice effect, diversion dams, canal operations, or debris are problematic for stage/discharge records, but can be handled by ADVM methods using stage as a variable in the index-velocity equation if necessary. This technique allows for more than one discharge at a given gage height and can reduce or eliminate the need for shift correction for changes in the control.

Study results at the three Colorado sites indicate that ADVM technology is a viable, though more expensive alternative to conventional USGS stage/discharge instrumentation. Much of the ADVM discharge computed for this study was within 5 percent of the USGS conventional stage/discharge, except at Clear Creek, where part of the ADVM discharge data were generally in the 5 to 10 percent range of percentage difference.

\section{Introduction}

Acoustic Doppler velocity meters (ADVM) have been used extensively by the U.S. Geological Survey (USGS) in many parts of the United States. ADVMs are indispensable for tidally affected streams, backwater-influenced gages, canals with lock-and-dam flow reversals, multiple adjustableheadgates influencing stage at a gage location, and for routine streamflow-gaging purposes. However, some stream conditions in Colorado, such as low flow, coarse-bed material, and effects from ice, may cause problems for ADVMs because of signal degradation. ADVMs have been developed for stream applications and are easy to install and maintain; ADVMs can produce discharge records where conventional methods may have difficulty or cannot be used. The Colorado Water Conservation Board (CWCB) needs streamflow data to help address instream water rights. In order to provide information about the usefulness of this technology in Colorado for the CWCB, the U.S. Geological Survey, in cooperation with the CWCB, began a study in 2004 to collect data to evaluate ADVMs in three different hydrologic settings.

This report evaluates the use of an ADVM for the computation of discharge records at three sites in Colorado: Bear Creek at Morrison (USGS station number 06710500, Colorado Division of Water Resources station BCMORCO), Clear Creek above West Fork Clear Creek, near Empire (USGS station number 06715000), and Redlands Canal near Grand Junction (USGS station number 390149108335101, Division of Water Resources station RLCGRJCO) (fig. 1). Streamflow records were computed at each site using conventional stage/discharge rating methods and stage-area and standard index-velocity rating methods. Comparisons were made between the two methods in order to determine the feasibility, advantages, problems, and potential opportunities to use ADVM technology in these and similar settings. ADVM and stage data were generally collected for this study from August 2004 through December 2004 (except for dry periods at Redlands Canal) and March 2005 through August 2005. 


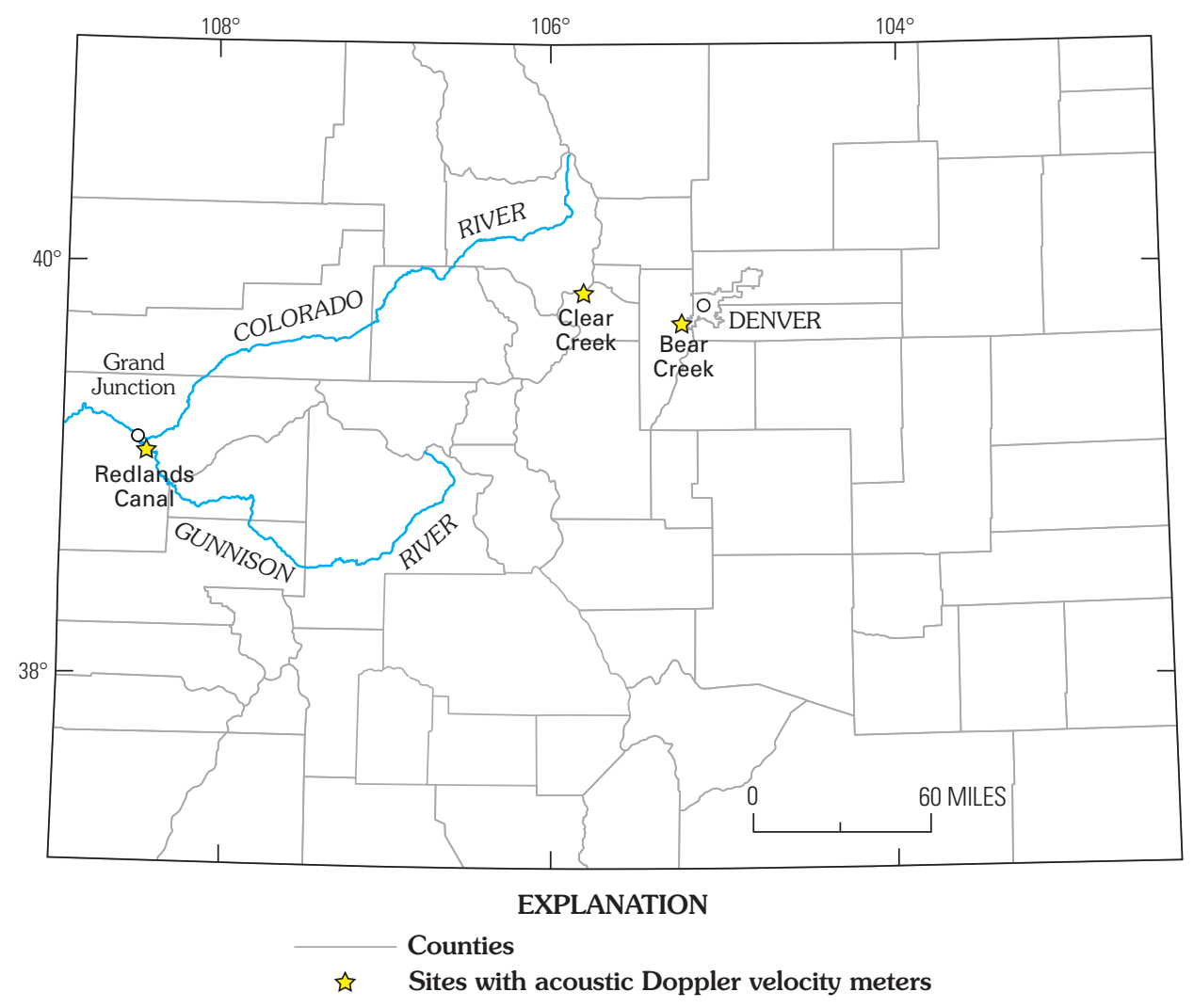

Figure 1. Map showing location of sites where acoustic Doppler velocity meters were evaluated in Colorado, 2004-2005.

\section{Evaluation Methods}

\section{Site Selection}

Site selection was based on four criteria set by the USGS with the input of the CWCB and the Division of Water Resources (DWR): (1) Active gage sites were selected to compare discharge records computed from conventional stage/ discharge methods to ADVM data, (2) water depth greater than about $1.5 \mathrm{ft}$ was needed to accommodate the acousticbeam geometry of the ADVM (at least one measurement cell, and no side-lobe interference or obstructions over the range of expected streamflows), (3) stream cross sections near the active gage (reference section) needed to be stable over the range of streamflows and not be subject to scour, fill, or excessive vegetative growth, and (4) the safety and security of the instrument was necessary because, unlike some other conventional data-collection instruments, the ADVM is located in the stream channel rather than in the gage house, where it is exposed to debris, ice, and possibly vandalism.

Three sites were selected. Bear Creek at Morrison was selected primarily because it had a stable stage/discharge control structure, a deep, stable pool, and restricted access. Clear Creek above West Fork Clear Creek near Empire was selected primarily because of its natural channel and mountainous setting; many gage sites in the USGS and DWR networks are located in the mountains. This site also has a large seasonal range in stage, a large range in sediment concentration, and a relatively secure location protected from debris by the stilling well located at the gage. Redlands Canal near Grand Junction was selected because the stage/discharge relation was insensitive (for example, the gradient in the canal is flat and changes in velocity affect discharge more than changes in stage), the site is a manmade conveyance (a site typical for ADVM implementation), and the site was of interest to the DWR.

All three sites were located at active gages with conventional stage measurement equipment. Stilling wells that are hydraulically connected to the stream or canal by intake pipes were in operation at all sites. Floats inside the stilling wells rise and fall with stage, driving digital encoders and chart recorders used for primary and backup stage records. Satellite telemetry equipment was used to transmit stage data at the three sites. ADVM data also were transmitted at Redlands Canal, while onsite retrieval of ADVM data to a USGS computer was used at the Bear and Clear Creek sites. 


\section{Theory of Acoustic Doppler Velocity Meter}

Acoustic instruments have been used in many parts of the country and are deployed in different ways to meet specific needs. For example: (1) Multiple transducers all pointed to one location in the stream to measure water velocity at a single point; (2) acoustic profilers are pulled across the channel surface and measure water velocity along a cross section; (3) up-looking profilers in fixed mounts on the channel bottom measure water velocity at several locations (at a set range) in the vertical stream profile at a single location and are capable of resolving vertical and bidirectional flow fields; and (4) transducers in fixed mounts (used in this study) that point across a channel at a fixed depth measure water velocity in specific ranges of a single cross section.

The type of instrument used in this study was a sidelooking bank-mounted instrument that allowed the average velocity to be determined by sampling the velocity of areas with discrete lengths called cells across a single cross section (fig. 2). For this study, a Sontek Argonaut SL 1500 kHz (Sontek, 2001) was used and is hereinafter called the acoustic Doppler velocity meter (ADVM). The ADVMs are self-contained transducers, mounted in the water and capable of generating acoustic (sound) energy pulses (pings). ADVMs measure the timing and frequency of the reflected pulses, store raw acoustic information, compute horizontal-velocity magnitude in two directions (each of two transducer beams), and resolve the velocity vector of the two beams. The transducers were pointed across the channel perpendicular to the general horizontal flow direction (Morlock and others, 2002; Sontek, 2001).

The ADVM transducers transmit and receive acoustic (sound) energy as pulses of high and low water pressure. The acoustic pulses move through water at rates that are affected primarily by water temperature (corrected by

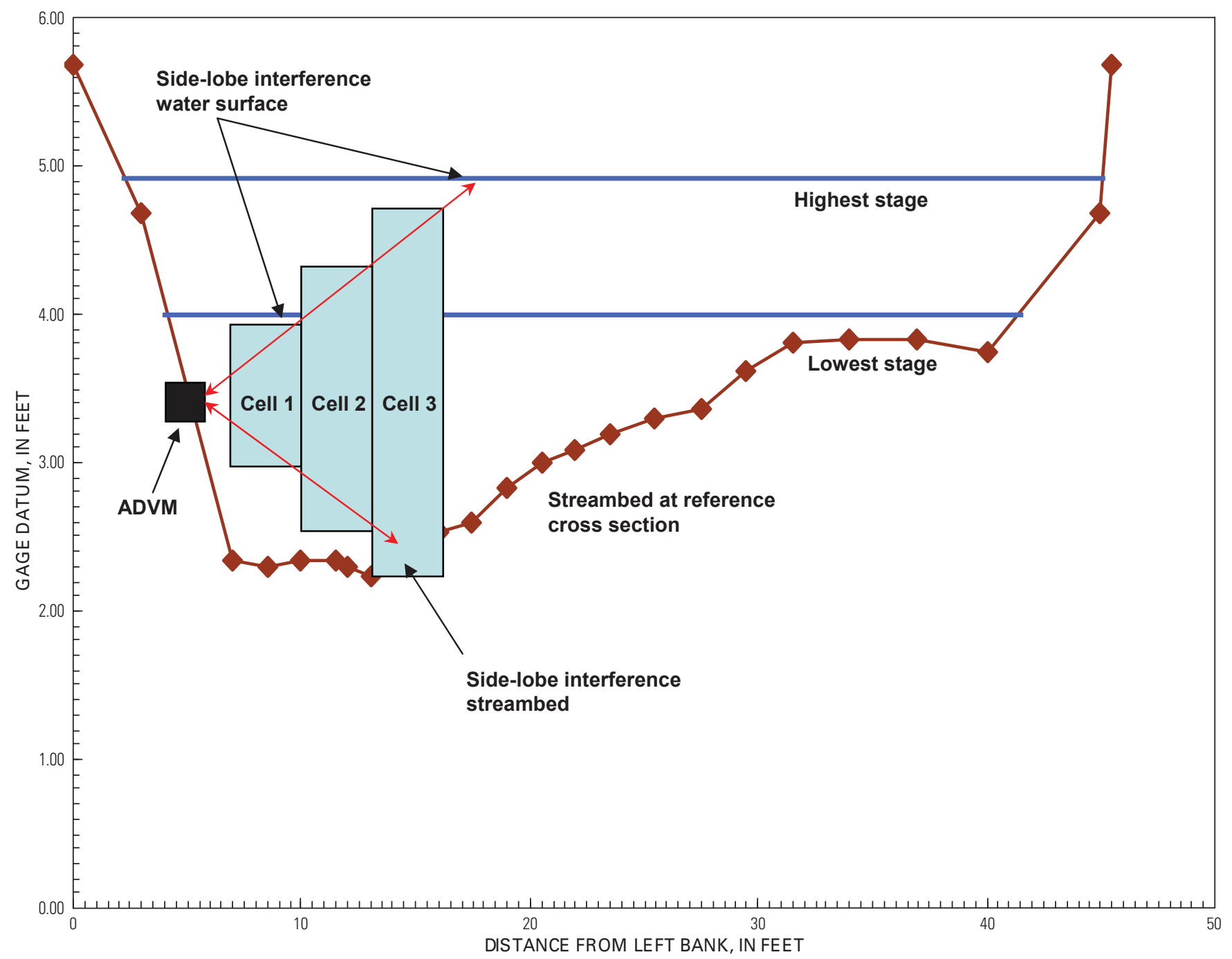

Figure 2. Reference cross section at Clear Creek showing how an acoustic Doppler velocity meter (ADVM) samples the average velocity. 
instrument), turbidity, and to a lesser degree, salinity (can be specified to a range to compensate). When acoustic energy strikes a particle in the water, some of the energy is reflected back along the path to the transducer (Morlock and others, 2002; Sontek, 2001). The velocity of the particle is assumed to be identical to the velocity of the water. The frequency of the reflected pulse is proportional to the velocity of the reflecting particle and, thus, the velocity of the water relative to the instrument. This principle is commonly known as the Doppler shift. The direction of flow, resolved by component vectors of the two transducer beams, along with the average velocity of the water allows the velocity of the water to be computed (Morlock and others, 2002; Sontek, 2001). A limitation of the operation of the ADVM, called side-lobe interference, happens when the beam strikes a solid object such as a rock, the streambed, or the water surface within the cell volume of interest (fig. 2). The strong reflection of acoustic energy from these boundaries causes extreme bias in the velocity calculation (Morlock and others, 2002; Sontek, 2001).

The instrument calculates the average velocity (frequency) within a certain range (cell) beginning and ending at a user-selected distance from the instrument. By this method, velocity can be measured in multiple distinct cells (fig. 2) at various distances from the instrument (Morlock and others, 2002; Sontek, 2001). This feature allows an acoustic or ADVM velocity (velocity derived from Doppler shift) to be based on one cell, a combination of cells, or an average of cells that gives the best fit to a regression equation with measured mean velocity. Measured mean velocity is the velocity derived from dividing the discharge by the cross-sectional area from a discharge measurement. Because stream velocity is variable at short time scales, the ping rate (sound pulses) of one per second was averaged over a minimum of 10 minutes at each site in this study.

\section{Streamflow Measurements}

Along with streamflow data that are continuously recorded at some USGS gaging stations, instantaneous streamflow and velocity were measured once per month (generally from April to October, except January and February) and every 1 to 2 months generally from November to March. DWR site visits at Redlands Canal were generally twice per month from April to October (irrigation season only). Streamflow was measured by USGS and DWR using a Price AA or Price pygmy current meters at Bear and Clear Creeks according to procedures given in Buchanan and Somers (1969) and Rantz and others (1982), and acoustic Doppler current meter (ADCP) at Redlands Canal according to procedures given in U.S. Geological Survey Office of Surface Water Technical Memoranda (2002a, b), Rehmel and others (2003), Oberg and others (2005), Ruhl and Simpson (2005), and Simpson (2001). The ADCP operates on similar principles as the ADVM, but only computes a mean velocity for the volume of water rather than a discharge.

\section{Ratings for Computation of Discharge}

Stage/discharge, stage-area, and velocity-index ratings were defined for the three sites using instantaneous-discharge measurements, readings of gage height and ADVM velocity, and a reference cross section near the gage. A stage/ discharge relation or rating curve is represented by a best-fit line through a graphical plot of stage in relation to instantaneous discharge values. The upper (high-flow) ends of the rating curves commonly are quasi-straight lines in log-log space and may even be computed from a least squares regression. The lower (low-flow) end of a typical rating curve does not have a linear relation and is hand-drawn for a best-fit through the data values. These rating curves can then be expanded to a tabular format that interpolates the stage/ discharge relation to the nearest $0.01 \mathrm{ft}$ (gage height above the gage datum), the precision of the stage record for numerical processing. A continuous record of stage (input) and the stage/discharge rating can then be used to compute the discharge record (output).

Stage-area ratings were developed for each site by measuring depth below or height above the water surface at multiple intervals at the reference cross-section, and then subtracting the depths from or adding the heights to, the stage to convert the cross-section bottom points to gage datum. A computer program, "AreaComp" (Michael S. Rehmel, U.S. Geological Survey, http://hydroacoustics.usgs.gov/indexvelocity/ software.shtml) was used in the study. The program accepts cross-section data in $\mathrm{x}$-y format and produces a stage-area tabular rating interpolated to the nearest $0.01 \mathrm{ft}$. The area term for discharge computations is determined from this stage-area rating input to the USGS Automated Data Processing System (ADAPS) (U.S. Geological Survey, 2003).

From each instantaneous discharge measurement, a mean velocity is computed. In addition, an ADVM velocity is recorded. Regression analysis was then used to examine the relation between the mean and ADVM velocities. The results of the analysis indicate how well ADVM velocity estimates measured velocity. The velocity-index method uses a rating developed from the relation of ADVM velocity and the mean velocity from the instantaneous discharge measurement. The mean velocity is derived from dividing the instantaneous discharge by the channel area of the reference cross section at the gage height during the measurement (fig. 2). The velocity-index relation can then be plotted and fitted with a regression line. The determination of discharge is then the product of this mean ADVM velocity and cross-sectional area. A continuous record of stage and ADVM velocity (inputs) with the use of stage-area and velocity-index ratings permits computation of discharge records (output) in ADAPS. If there are complex relations between stage and discharge, such as backwater effects or overbank flooding conditions, a multi-linear regression analysis based on velocity and stage can be more accurate than the single linear regression analysis. 


\section{Discharge Records Computations}

Site-visit data were used in the analysis and computation of discharge from continuous stage-data collected at monitoring stations according to procedures given in Rantz and others (1982) and Kennedy (1983). Gage-height corrections were applied to the stage record if the recording-gage reading differed from the reference gage at the time of the site visit. Variable shifts to stage were applied before computing discharge if measurements indicated a deviation (percent difference) from the stage/discharge rating greater than the error (in percent) indicated by the hydrographer rating of the instantaneous discharge measurement at the time of the visit. If measurement trends indicated a consistent pattern of shifts, the corrected and shifted stage was then used as input to the stage/discharge rating to compute discharge.

Computation of discharge using ADVM velocity also required the use of the corrected gage-height record. The stagearea rating was used to compute area from the corrected gageheight record. The area was then multiplied by mean velocity determined from the ADVM velocity record and the velocityindex rating to compute discharge (Morlock and others, 2002). No shifting to the velocity-index rating was required for channels with stable reference cross sections. The ADVM method is generally not sensitive to changes in the gage control unless the centroid of flow is changed substantially, which reduces the level of complexity and potential for error.

\section{Evaluation of the Acoustic Doppler Velocity Meter for Computation of Discharge Records}

\section{Description of the Study Site at Bear Creek}

The altitude of the Bear Creek watershed ranges from about 6,000 $\mathrm{ft}$ (NAVD88) at the gage near Morrison to about $14,000 \mathrm{ft}$ (NAVD88) approximately $30 \mathrm{mi}$ west of the ADVM gage. The watershed is forested, and the stream is impounded by a small dam near about $10 \mathrm{mi}$ to the west. Below the reservoir the stream flows into a semiarid, steep-walled, highgradient canyon down to the gage.

The DWR gaging station is located near the mouth of Bear Creek canyon at the town of Morrison (fig. 1). A stilling well for the gage is located on the left bank just upstream from a large, notched, concrete weir that is the gage-height control. The ADVM was mounted on a steel bar driven into the streambed just upstream from the stilling well near the left bank.

\section{Hydrology and Streamflow Conditions}

Snowmelt is the primary source of water to Bear Creek, and a large proportion of annual flow occurs in the summer months. Spring and summer thunderstorms can result in additional discharge peaks (fig. 3). Streamflow diversions and wastewater discharges upstream from the gage affect streamflows. The streambed material is cobble-sized gravel, and flow is turbulent in the reach upstream from the gage. The gage pool behind the weir had a shallow, sandy-silt layer over the cobbles, and the right bank developed a 0.5 - to 1 -ft accumulation of silt and a thick macrophyte bed in summer and fall of 2004 and 2005. Some of this material was scoured at high flow, but the effect on the reference cross section was believed to be minimal. The water surface behind the weir is relatively smooth even at high flow. The centroid of flow was generally in line with the notch in the weir, to the left of channel center. Good stage record was expected here because of the solid and sensitive control structure and the smooth water surface of the gage pool.

\section{Comparison of Velocity-Index and Stage/ Discharge Ratings}

The computation of ADVM discharge record at Bear Creek required two velocity-index ratings, one for the September to December 2004 period (rating number 1) and one for the March through August 2005 period (rating number 2). Ice movement in the control pool where the ADVM was located knocked the staff-mounted ADVM over onto the streambed in January 2005. Because there was some uncertainty in restoring the exact position of the instrument, a new rating was developed beginning in March 2005. Both ratings (fig. 4) used cell 1 , located from 1.64 to $4.92 \mathrm{ft}$ from the ADVM transducer. Rating 1 had an adjusted coefficient of determination $\left(\mathrm{r}^{2}\right)$, standard error, and standard error as a percent of the mean velocity of the measured discharge, $0.995,0.023 \mathrm{ft} / \mathrm{s}$, and 3.1 percent, respectively. Rating 2 had an adjusted coefficient of determination $\left(\mathrm{r}^{2}\right)$, standard error, and standard error as a percentage of the mean velocity of the measured discharge $0.997,0.026 \mathrm{ft} / \mathrm{s}$, and 2.7 percent, respectively. The $\mathrm{r}^{2}$ values indicated a good linear relation with no influence from stage. For rating 1 the percent difference between the velocity derived from instantaneous discharge measurements and those derived from the ADVM ranged from -2.7 to 6.7 percent. For rating 2 , the percent difference between the velocity derived from instantaneous discharge measurements and those derived from the ADVM ranged from -3.6 to 4.2 percent. The percent differences were considered to have acceptable rated measurement error (less than 5 percent is rated good). Thus, no shifts to the velocity-index rating were necessary at this site. Periods of missing ADVM velocity record were generally caused by problems with battery power and incorrect instrument settings.

The stage/discharge rating at Bear Creek (rating number 23, Steve Barrett, written commun., Division of Water Resources, 2005) developed by the DWR was used for this study. Stage shifts based on discharge measurements during the year were applied (shift analysis by USGS). Stage record was provided by DWR, and corrections of the gage-height record to base gage were minimal. The stage record was mostly complete, and stage record for ice-affected days between November and February were based on analysis of the gage height, discharge measurements, and water-temperature records. No estimates for missing or ice-affected record were made. 


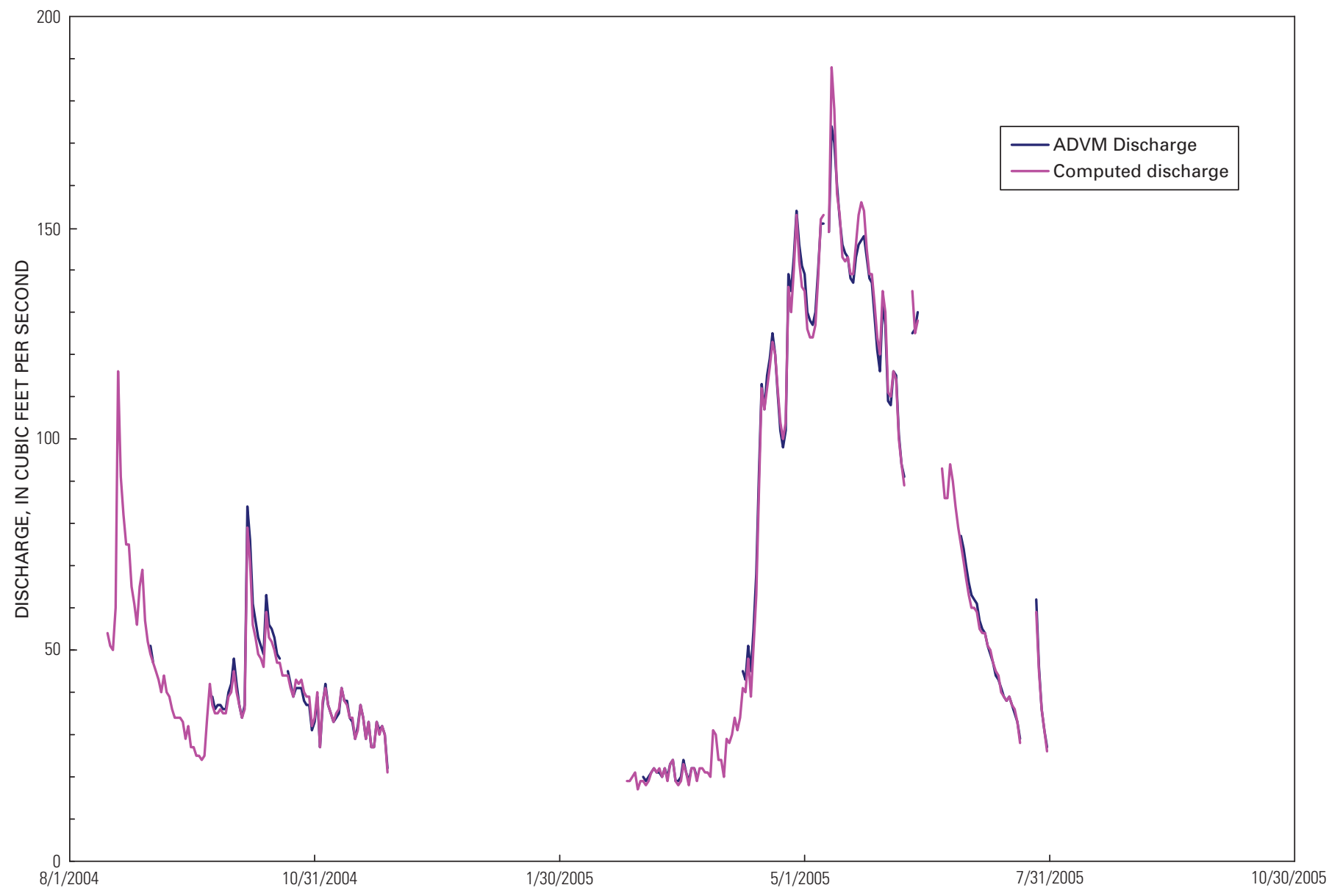

Figure 3. Comparison of mean daily discharge produced by conventional methods (computed) and by acoustic Doppler velocity meter (ADVM), Bear Creek at Morrison, Colorado.

\section{Evaluation of Acoustic Doppler Velocity Meter Performance at Bear Creek}

In general, the ADVM discharge compared well to computed discharge (conventional stage/discharge relation) (figs. 5-7). Most of the percent differences in daily mean values ranged from positive and negative 5 percent with a maximum of about 15 percent. At the upper end of the discharge range (more than $150 \mathrm{ft}^{3} / \mathrm{s}$ ), the ADVM tended to underestimate discharge compared to the computed discharge (fig. 5). This relation could be a result of the lack of definition of a shift at the upper end of the stage/discharge rating. It also may be a result of the extension of the velocity-index rating above $135 \mathrm{ft}^{3} / \mathrm{s}$, the highest instantaneous measurement during the ADVM installation period.

Ice was a problem for the ADVM at Bear Creek. Failure of the staff mount from ice movement indicates more reinforcement of the staff by supports from the bank would be necessary in this ADVM configuration for winter conditions. Ice affected the velocity data such that little useful ADVM record was obtained after water temperatures dropped to $0^{\circ} \mathrm{C}$ (Ben Macone, SonTek/YSI, Inc., oral commun., 2005) (fig. 8). Because ice was in the stilling well (Isopar oil tube was used for part of winter) or backwater from ice disrupted the stage/discharge relation, the stage record was not always reliable and winter ADVM discharge computations were not possible.

At the onset of ice effect, about November 27, 2004, the signal-to-noise ratio from the ADVM began to decrease as water temperature dropped to $0^{\circ} \mathrm{C}$ (fig. 8). The velocity and flow direction also began to show large, incoherent fluctuations. After many days of ice cover, the water began to warm about December 10, 2004, and the ADVM signal-to-noiseratio, velocity, and flow direction returned to a typical ice-free pattern. On December 11, during a site visit, ice cover on the weir was observed.

ADVM data have been successfully collected under ice cover in North Dakota (Lambrecht, 2004) (Jason Lambrecht, U.S. Geological Survey North Dakota Water Science Center, oral commun., 2006), Canada (Wang, 2004), and Minnesota (Dan Daily, U.S. Geological Survey Minnesota Water Science Center, oral commun. 2005). In these instances, however, streams were deeper and were subject to long periods of continuous ice cover. At Bear Creek, the ADVM was 
A

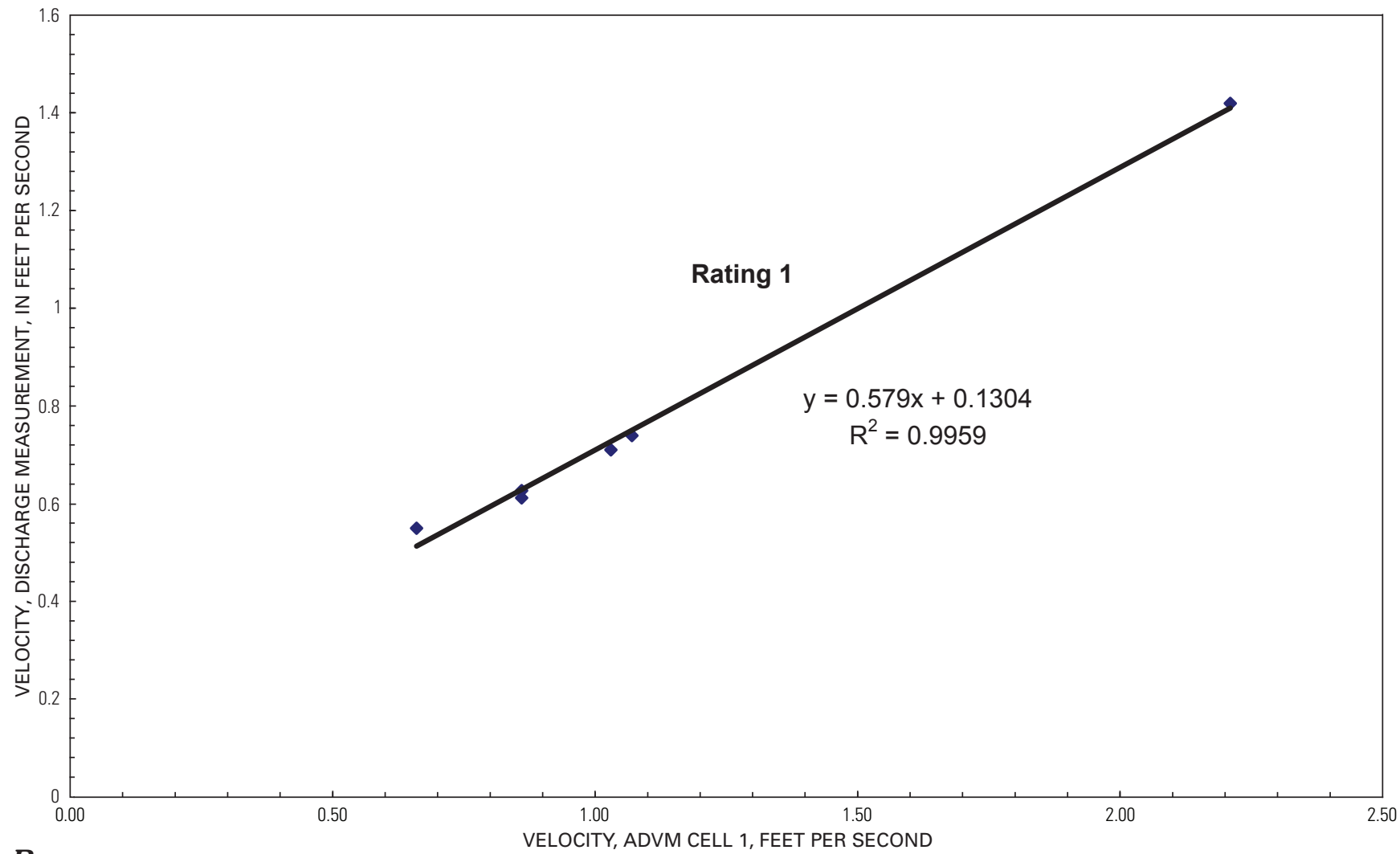

B

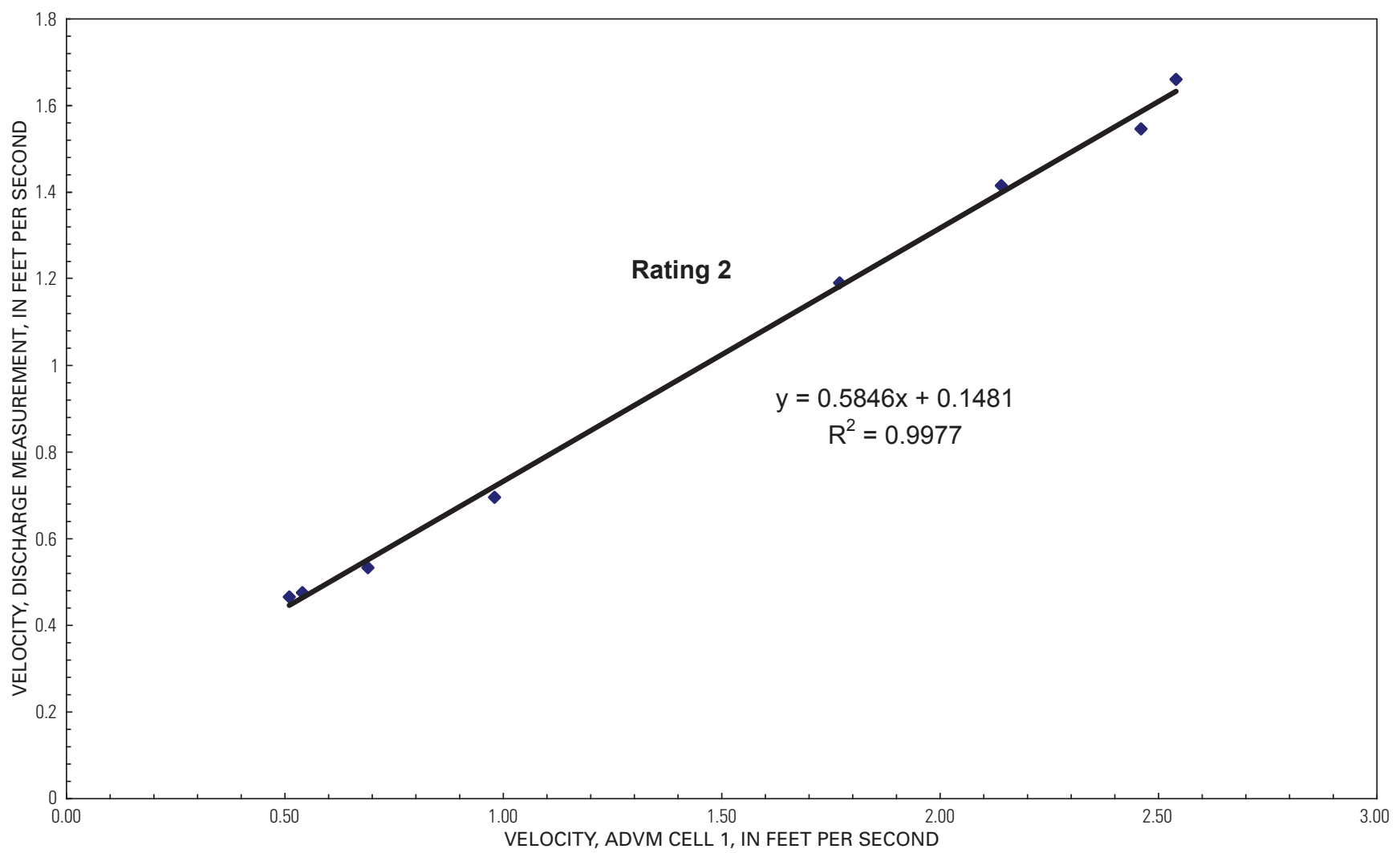

Figure 4. Velocity-index ratings for Bear Creek at Morrison, Colorado: $(A)$ rating 1, velocities measured September to December 2004, and (B) Rating 2, velocities measured March through August 2005. 


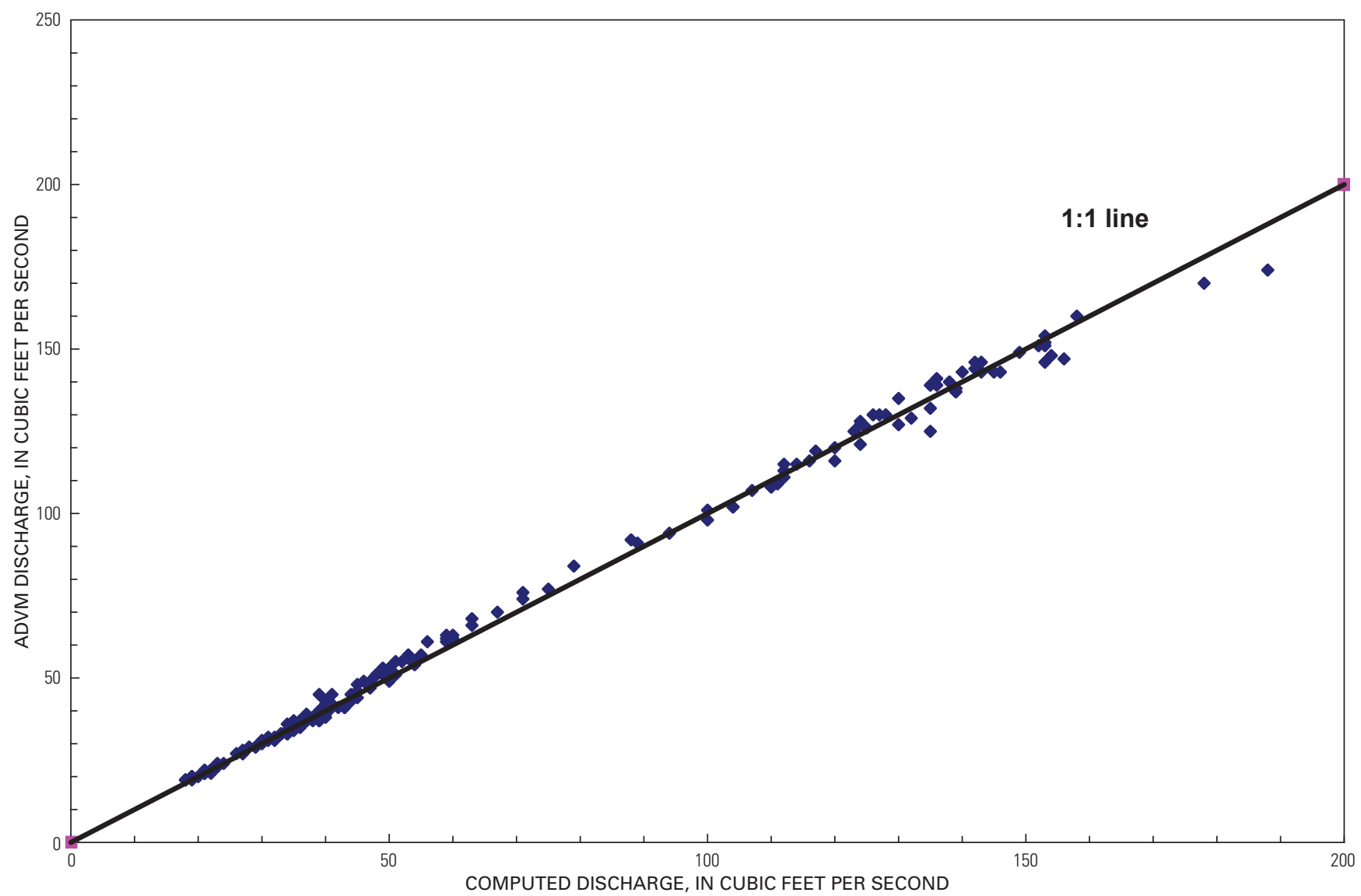

Figure 5. Comparison of computed and acoustic Doppler velocity meter (ADVM) discharge, Bear Creek at Morrison, Colorado.

mounted relatively close to the streambank, making it vulnerable to icing on the instrument. Bear Creek is relatively shallow and is subject to midwinter thaws and partial ice cover. These conditions could contribute to the formation of frazil ice (small floating pieces of ice unable to form a continuous sheet because of turbulence), anchor ice (frazil ice particles attached to the streambed), and midwinter breakups of ice cover (floating chunks of ice) (Burgi and Johnson, 1971; C.C. McDonald, U.S. Geological Survey, Boston, written commun., 1943).

The formation of ice could affect the ADVM and degrade the accuracy of the velocity data. Cold climates with gradual formation of thick ice cover tend to produce less frazil ice. Conversely, radiant heat escapes from the streambed materials under no ice cover on clear nights and is thought to contribute to the formation of anchor ice. Upstream watersurface turbulence, sections of the stream partly covered by ice, and exposure to wind are factors that produce more floating and frazil ice. During midwinter thaws, ice can collapse and be transported to ice-covered reaches potentially causing ice jams (Melcher and Walker, 1992; Burgi and Johnson, 1971; C.C. McDonald, U.S. Geological Survey, Boston, written commun., 1943; Hoyt, 1913). In addition, changes in stage after ice cover has initially formed cause water to break through the ice and flow over the ice cover. This phenomenon can result in multiple layers of thick ice and sometimes snow between the layers if snow has fallen between successive breakout events, which also can degrade ADVM velocity data.

Although ice is probably a strong reflector of acoustic energy and could result in high signal-to-noise ratios, high ratios were not observed at Bear Creek during the NovemberDecember ice-affected period; under-ice conditions were not known. The instrument, located within a few feet of the left bank, may have been encased in ice, or ice was in front of the transducer causing signal strength to be dissipated within the blanking distance $(1.64 \mathrm{ft})$ before reaching the cells. The data characteristics are unknown for that condition. A study specifically aimed at determining under-ice conditions would be necessary to explain the ADVM data (fig. 8), but such an investigation was beyond the scope of this study.

\section{Description of the Study Site at Clear Creek}

The altitude of the Clear Creek watershed ranges from about 8,500 ft (NAVD88) to more than14,000 ft (NAVD88) approximately $15 \mathrm{mi}$ to the southwest of the ADVM gage. The watershed is covered mostly by coniferous forest, except 


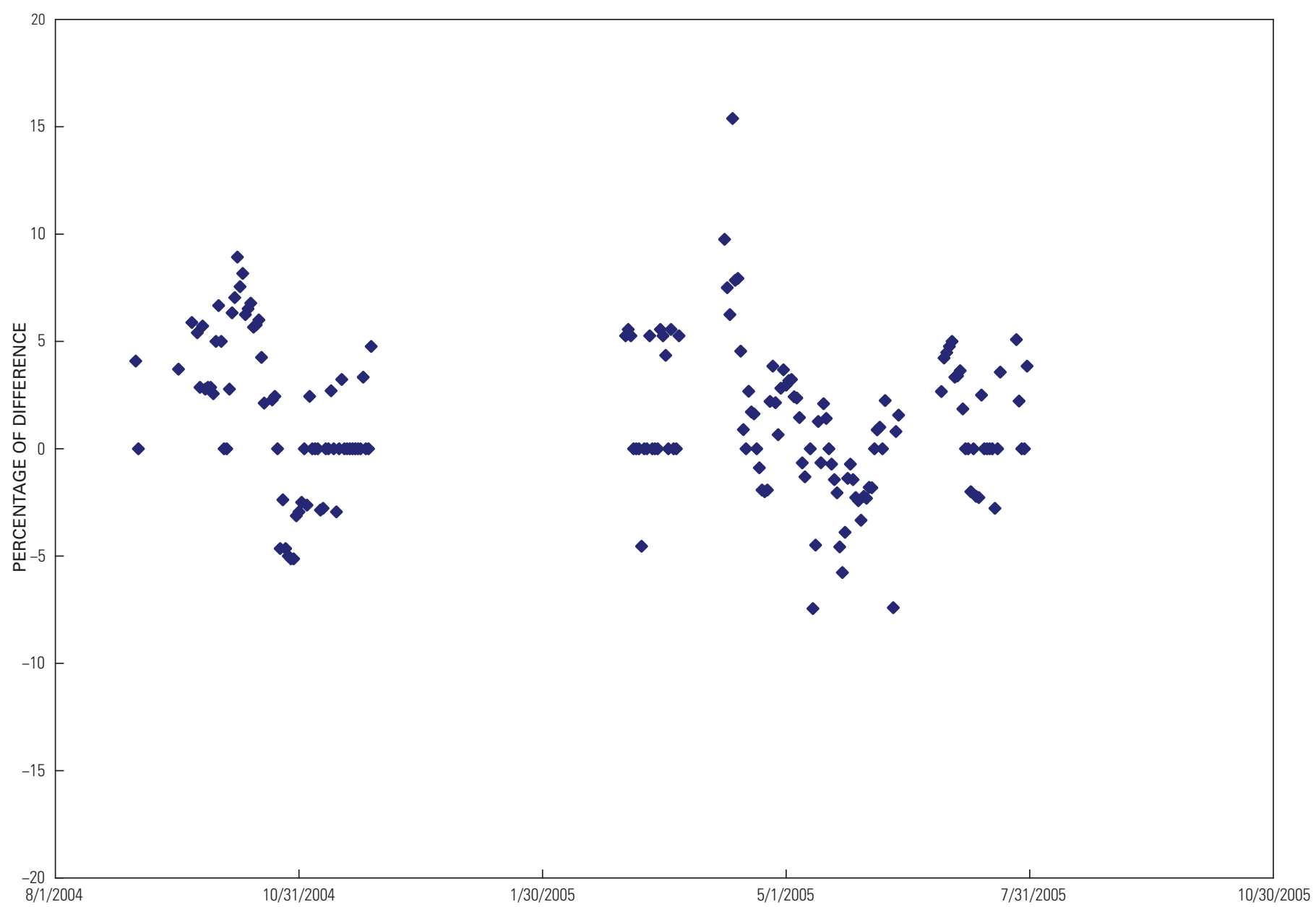

Figure 6. Percentage of difference between daily mean discharge determined by acoustic Doppler velocity meter and that computed by the stage/discharge relation, Bear Creek at Morrison, Colorado.

in the highest areas above the timberline where tundra vegetation is predominant. Precipitation is mainly in the form of snow, which falls primarily from September to May. Mountain thunderstorms are common from June to September but contribute little to the total annual precipitation. Mean annual precipitation ranges from 30 to 40 in. (Doesken and others, 1984).

\section{Hydrology and Streamflow Conditions}

Snowmelt runoff between May and July was the primary source of water in water year 2005. A summer thunderstorm in early August resulted in an additional small discharge peak (fig. 9). Upstream diversions for power generation and transmountain diversions can affect streamflow to a minor degree during high flow. The streambed consists of cobbles and boulders, which causes flow to be turbulent and the water surface to be uneven near the gage and the ADVM. The gage pool was relatively shallow (less than 3 to 4 feet deep) but stable. The control for stage was a rock riffle approximately 50 to $100 \mathrm{ft}$ downstream from the gage. The centroid of flow was generally near the left bank so the ADVM was installed near the left bank. The ADVM was located about $200 \mathrm{ft}$ downstream from a box culvert. A large signal return was shown in the ADVM diagnostics as a steep rise in amplitude about $8.20 \mathrm{ft}$ from the instrument. This signal was probably side-lobe interference that would affect cells 2 and 3 (fig. 2).

\section{Comparison of Velocity-Index and Stage/ Discharge Computations}

An ADVM was installed at the Clear Creek site in March 2005. A single velocity-index rating was used through August 2005 (fig. 10). The velocity-index rating for the discharge record used cell 1, located from 1.64 to $4.92 \mathrm{ft}$ from the ADVM transducer. The rating had an adjusted coefficient of determination $\left(\mathrm{r}^{2}\right)$, standard error, and standard error as a percentage of the mean velocity of the measured discharge, 0.995, 0.093 $\mathrm{ft} / \mathrm{s}$, and 3.8 percents, respectively. The $\mathrm{r}^{2}$ value indicated a 


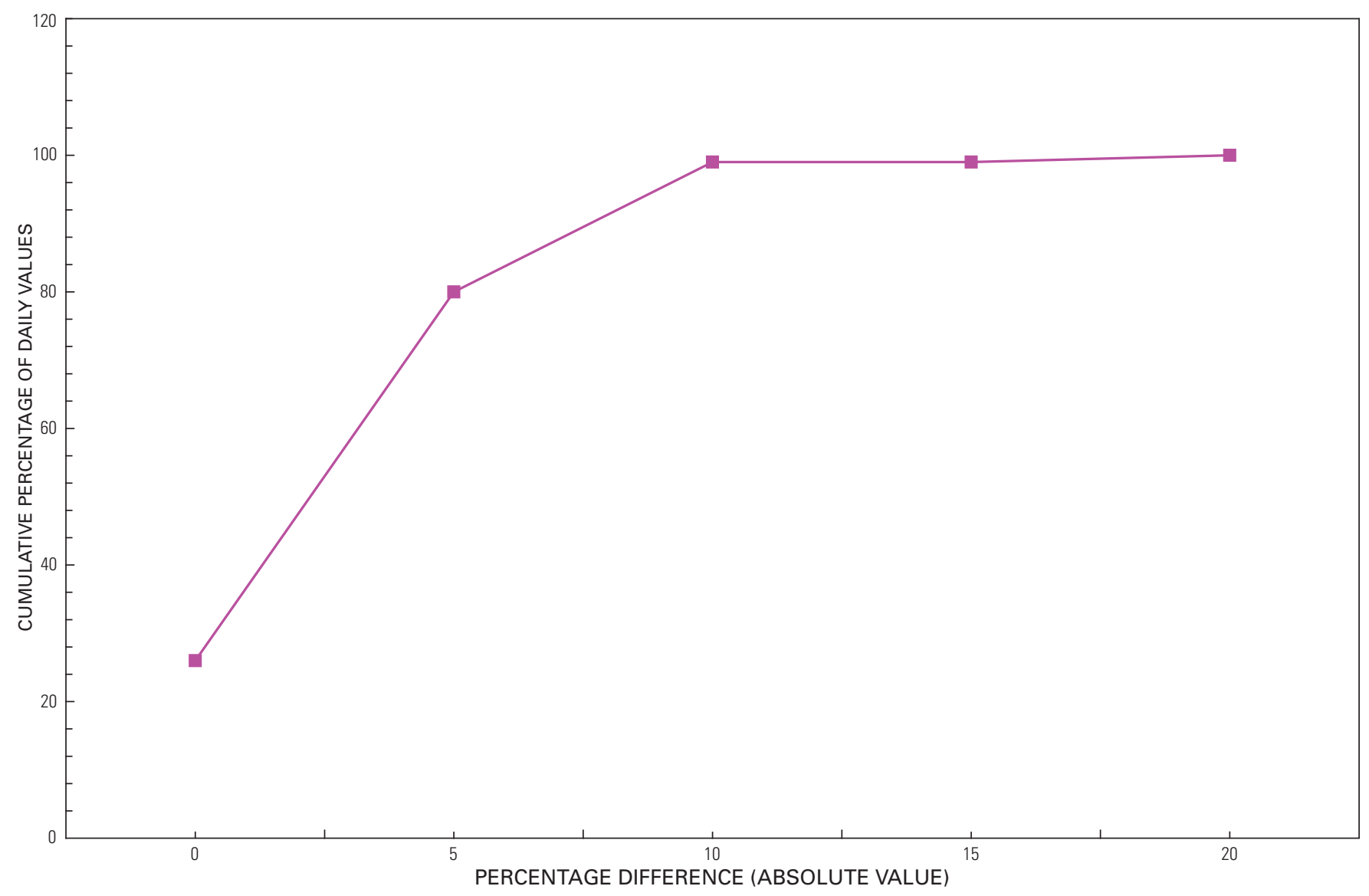

Figure 7. Cumulative percentage of absolute difference in relation to absolute percentage of difference between acoustic Doppler velocity meter (ADVM) and computed discharge, Bear Creek at Morrison, Colorado.

good linear relation with no influence from stage. For rating 1 , the percent difference between the velocity derived from instantaneous discharge measurements and those derived from the ADVM ranged from -6.47 to 14.8 percent. The percent differences were considered to have acceptable rated measurement error of fair to good (less than 5 percent is rated good, less than 8 percent is rated fair). Thus, no shifts to the velocityindex rating were necessary at this site. Periods of missing ADVM velocity record were generally caused by problems with battery power and incorrect instrument settings. Comparisons of discharge generally showed higher discharges for the ADVM than for the computed-discharge at Clear Creek for the entire period (fig. 11). The water was shallow and clear until mid-April, which contributed to problems with velocity data (fig. 12) until the stage began to rise in mid-May. A change in percent difference of computed and ADVM discharges was noticed in mid-July through the end of the study period in August (fig. 12) and was confirmed by a velocity-gage height plot that revealed some hysteresis (non-linearity between 1 and $2 \mathrm{ft} / \mathrm{s}$ velocity)(fig. 13). This hysteresis indicates that some change has occurred such that the same stage (gage height) does not produce the same ADVM velocity on the rising and falling limb periods of the hydrograph. Debris probably did not cause the high bias (indicated by hysteresis) in ADVM discharge values (small branches were removed from the ADVM in August 2005) from about mid-July to early August (fig. 12) because debris in front of the transducers would probably have caused a low bias. Instead the ADVM mount could have moved slightly by settling, leaning, or turning; this movement would have altered the transducer alignment and caused a distinct deviation from the rating (Ruhl and Simpson, 2005). Thus, the ADVM discharge values during this period are not reliable due to instrument shift (fig. 9).

The stage/discharge rating (rating number 4) at Clear Creek was used for the entire year. Stage shifts based on discharge measurements during the year were applied (shift analysis by USGS). Stage record was generally good and corrections of the gage-height record to base gage were minimal. The stage record was mostly complete and ice-affected days between November and February were identified by analysis of the gage height, discharge measurements, and water-temperature records. No estimates for missing or ice-affected record were made. 
FileName: DEFB1042.arg (Argonaut- SL 1500 kHz)

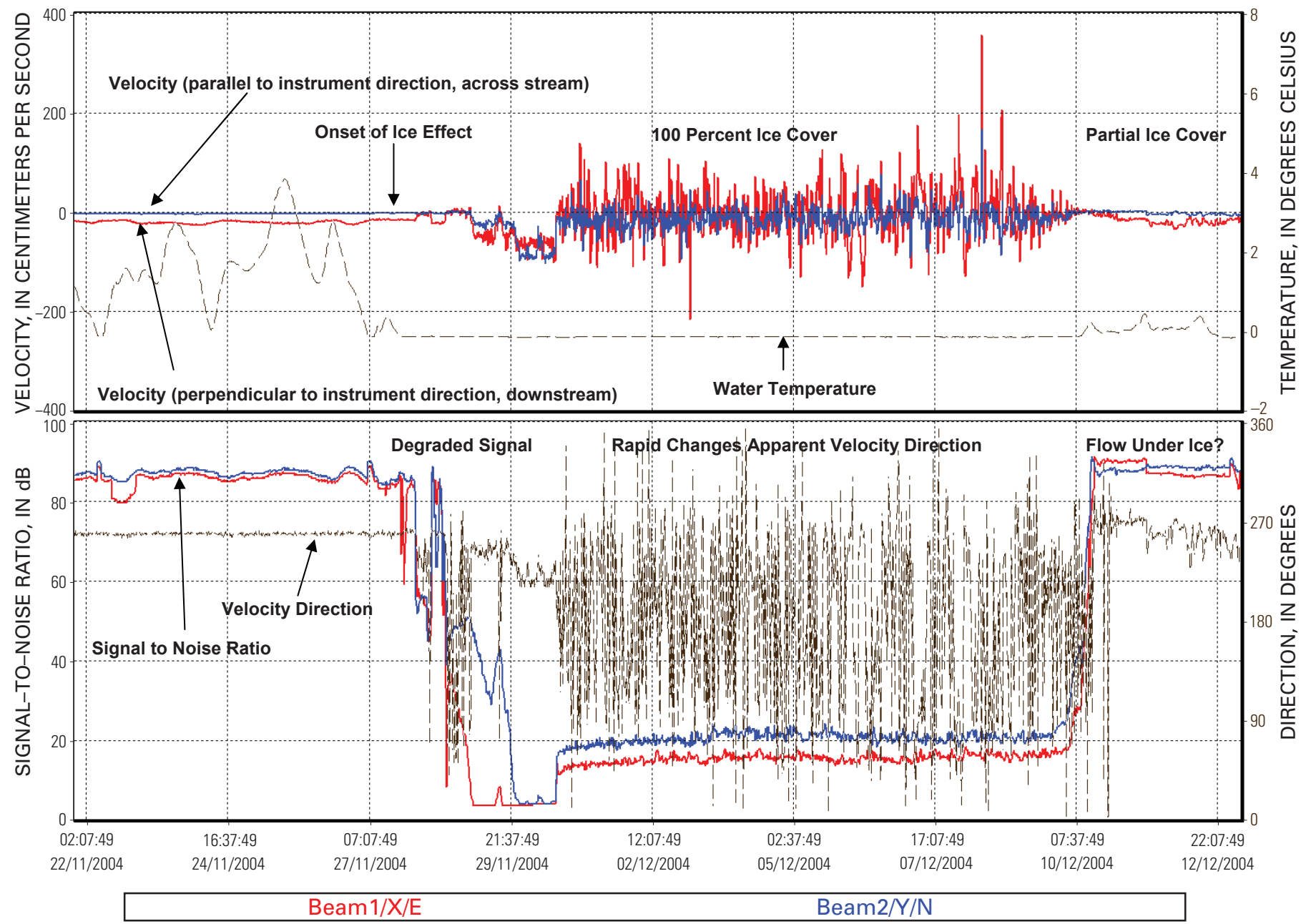

Figure 8. Response of the acoustic Doppler velocity meter during under-ice conditions, Bear Creek at Morrison, Colorado, November 11 to December 12, 2004.

\section{Evaluation of Acoustic Doppler Velocity Meter Performance at Clear Creek}

In general, the ADVM discharge compared reasonably well to computed discharge (figs. 14 and 15). Most of the percent differences in daily mean values ranged from about positive 10 to negative 5 percent and a maximum of about 20 percent (fig. 15). The patterns in the percent differences with time are thought to be a result of site-specific influences on the stage/discharge record at Clear Creek. This is indicated by comparing the percent differences between ADVM discharge at Clear Creek and the discharge computed from the stage/ discharge rating at Clear Creek, and the percent differences between discharge computed from a stage/discharge rating at another upstream site (Clear Creek above Georgetown Lake, near Georgetown (CG); 394308105413800) (fig. 14). If the ADVM alone was causing the trends (the patterns of the graphed points) in percent difference at Clear Creek, a similar pattern in percent difference would not be expected at the CG upstream site. But the percent difference trends at the CG site are similar to the ADVM percent difference trends, indicating that some of the trends at the Clear Creek site are independent of the ADVM. These trends are probably the result of stage shifts that are not well defined and affect the accuracy of the Clear Creek stage/discharge computations (short-term shifts in the control at the study site that were not indicated by discharge measurements) at the Clear Creek site. The ADVM is not affected by changes in the control (which cause stage shifts), thus, the ADVM discharge may be more reliable than the computed discharge in many instances.

The ADVM at Clear Creek seemed to have been affected by cold weather during April and early May (fig. 12), causing a low bias in velocity and discharge data. During the late April- May period (fig. 16), daily decreases in signal amplitudes and concurrent increases in instrument noise occurred when the water temperature decreased each 


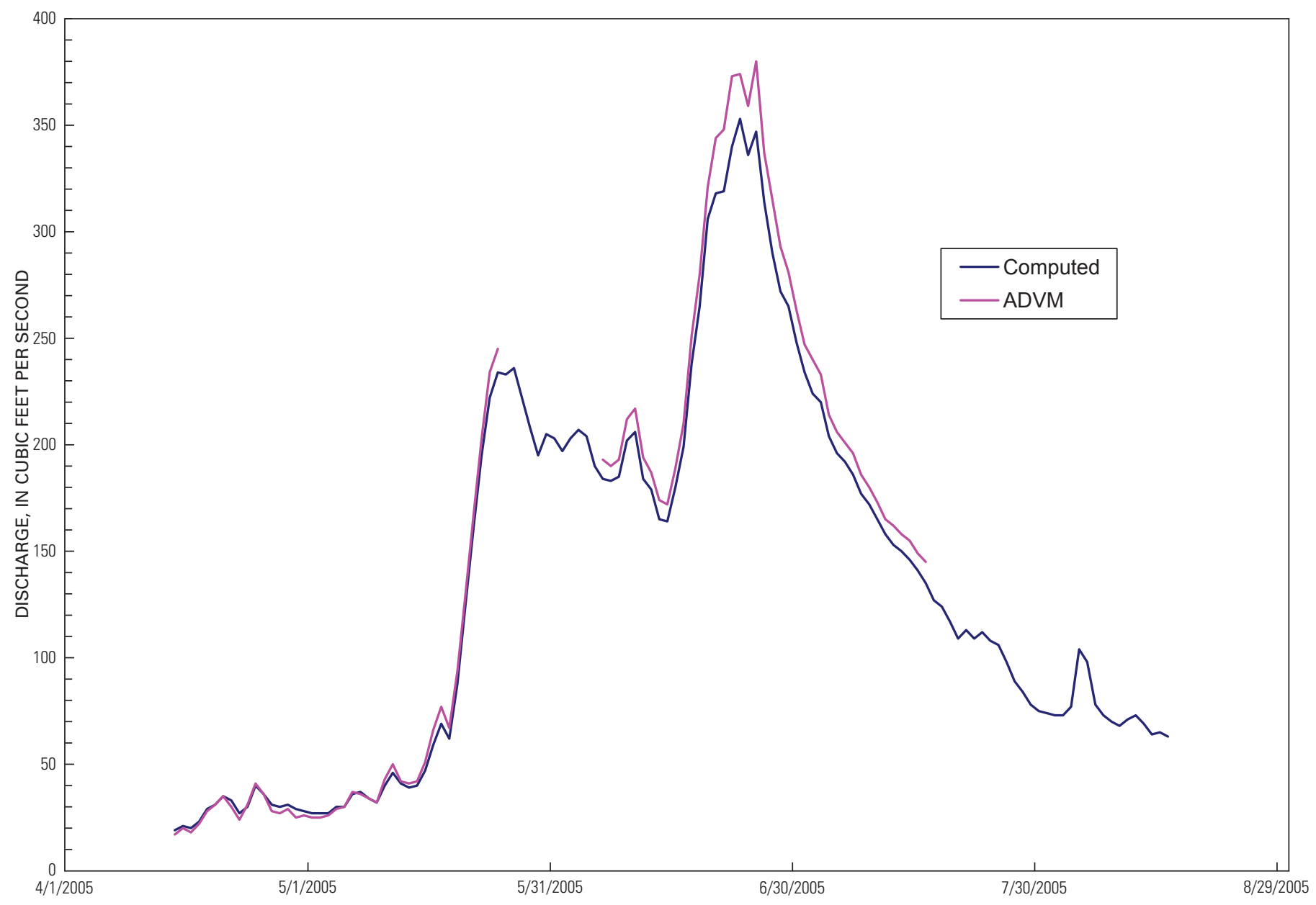

Figure 9. Comparison of mean daily discharge produced by conventional methods (computed) and by acoustic Doppler velocity meter (ADVM), West Fork Clear Creek near Empire, Colorado. Breaks in the graphs represent periods of no data.

night (for 6 to 8 hours). This daily (diurnal) decrease seemed to indicate an ice effect. However, water temperatures were never below freezing, and, as previously mentioned for Bear Creek, ice formation would probably tend to increase signal strength (strong reflectors). Stage was stable and, thus, did not seem to affect the discharge data. During these periods of signal problems, the ADVM automatically adjusted the cell endpoint back to the blanking distance $1.64 \mathrm{ft}$ from the instrument (fig.16), resulting in signal strengths of zero; velocities were then computed from instrument noise. It is not known whether an independent increase in instrument noise caused the signal-to-noise ratio to decrease, in turn causing the instrument to adjust the cell endpoint back to the blanking distance (the distance from the transducer at which the instrument begins to "listen" for signal returns). Extremely clear water could cause decreases in signal amplitude (backscatter), decreasing signal-to-noise ratio, and, thus, adjustment of cell endpoints. Mid-April and May is generally a period of low turbidity (Stevens, 2001). A further indication that water clarity might have been causing a low bias was that the signal amplitude generally began to increase on the rising limb of the diurnal velocity, and decreased on the falling limb after the peak velocity. This timing is similar to the diurnal changes in streamflow, turbidity, and sediment concentration in snowmelt-dominated mountain streams. Also, the signal problem disappeared at the beginning of the snowmelt runoff period (about May 9), a time when turbidity generally rises substantially for all parts of the diurnal cycle (Stevens, 2001).

\section{Description of the Study Site at Redlands Canal}

The Redlands Canal diversion dam is located on the Gunnison River, 3 mi upstream from the confluence with the Colorado River on the southwest edge of Grand Junction (fig. 1). The area is arid rangeland at an elevation of about $4,500 \mathrm{ft}$ (NAVD88). The canal was excavated in soil and sedimentary rock. The canal is used for power generation and irrigation (Kuhn and Williams, 2004).

Discharge is controlled at the diversion dam, which diverts water from the Gunnison River during the irrigation 


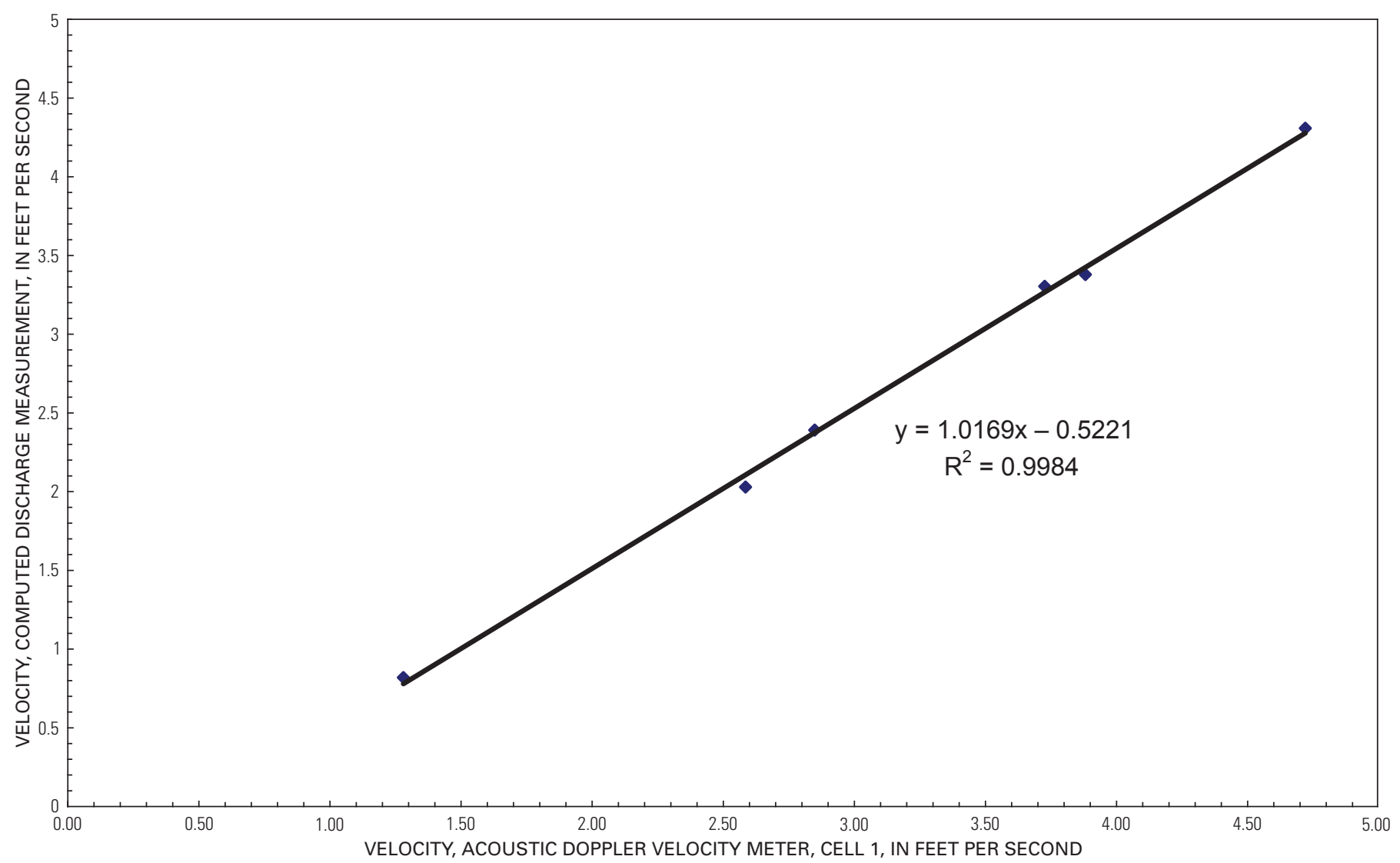

Figure 10. Velocity-index ratings for Clear Creek above West Fork Clear Creek near Empire, Colorado.

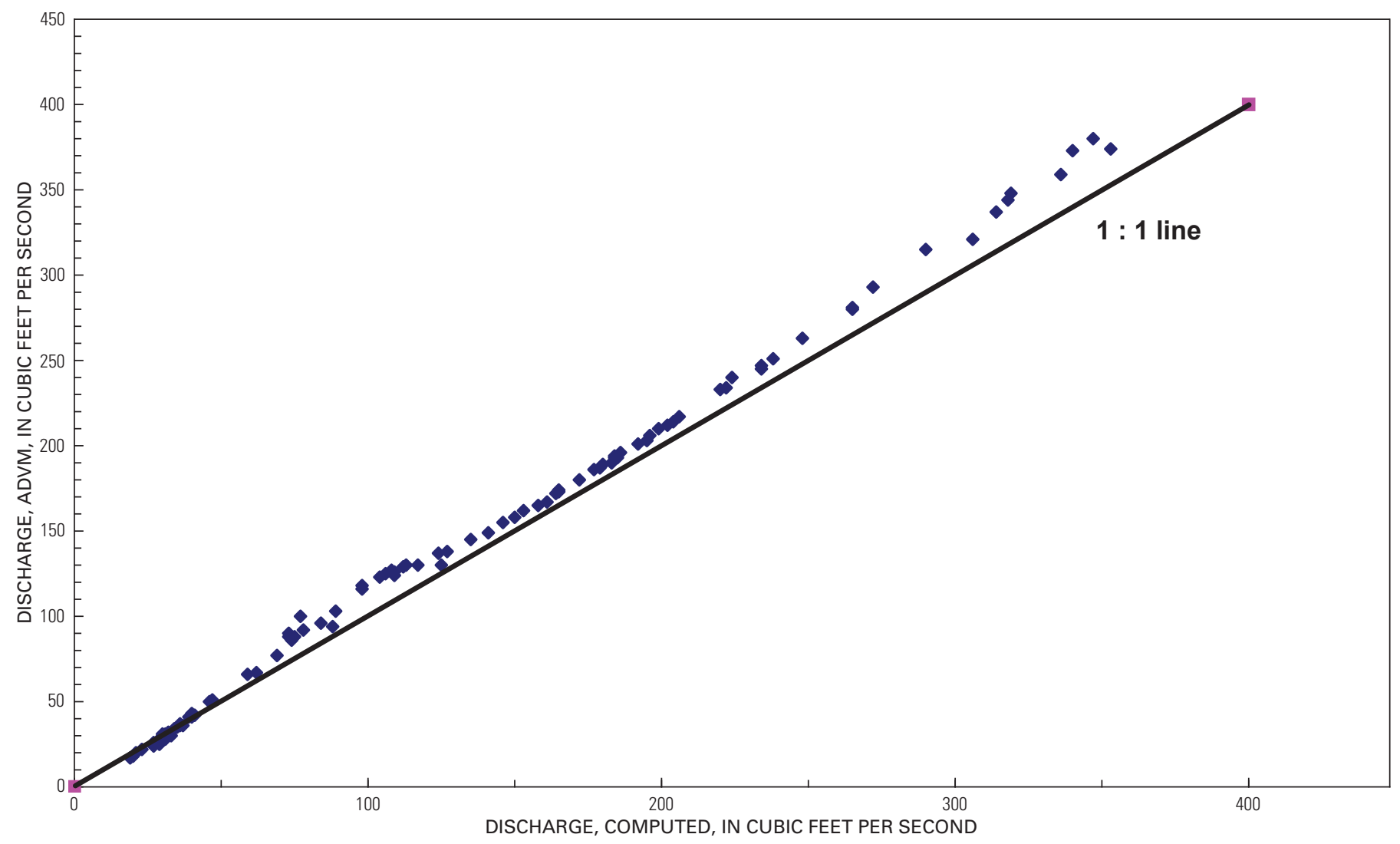

Figure 11. Comparison of computed and acoustic Doppler velocity meter (ADVM) stage discharge, Clear Creek near Empire, Colorado. 


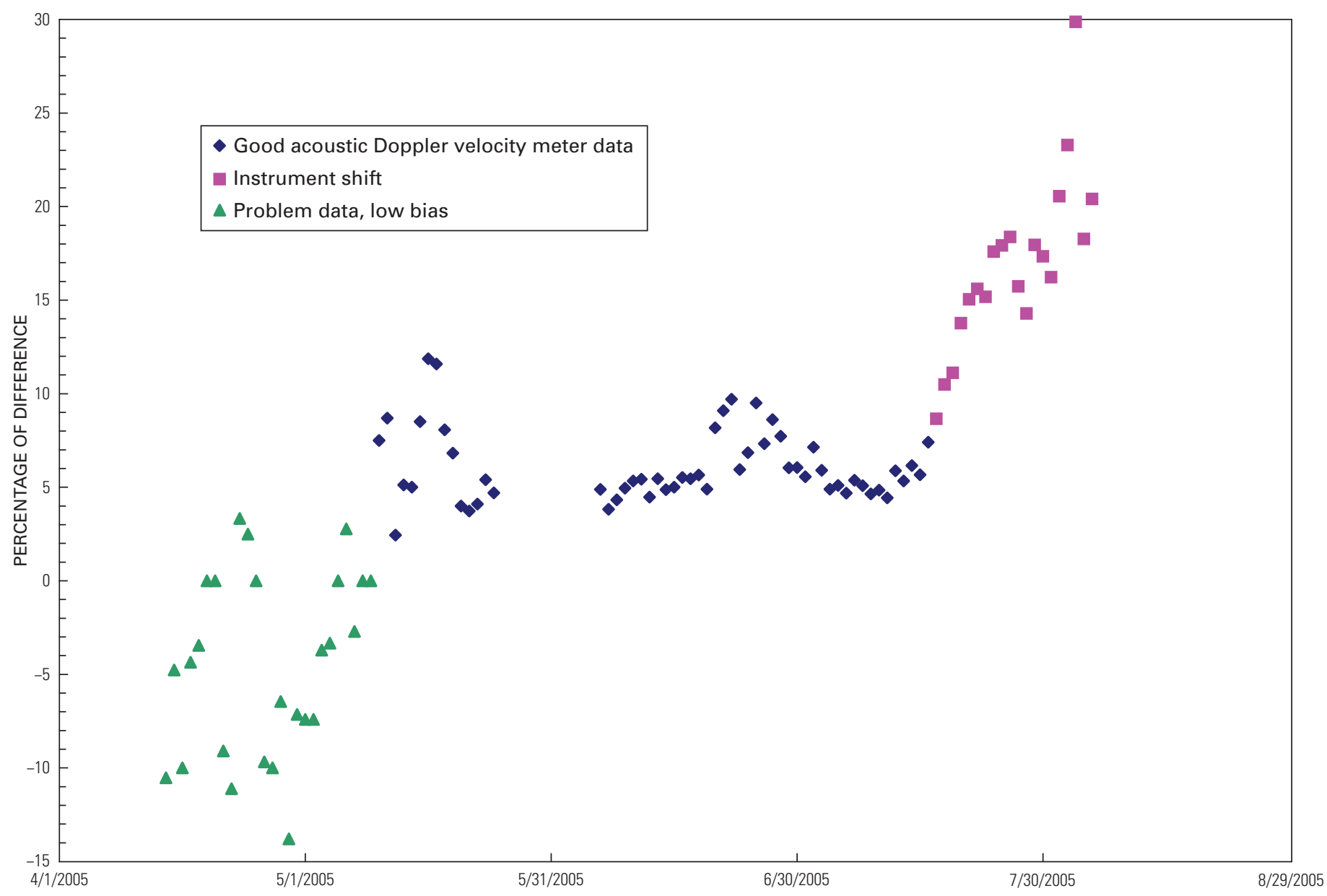

Figure 12. Percentage of difference between daily mean discharge determined by acoustic Doppler velocity meter and those computed by the stage/discharge relation, Clear Creek near Empire, Colorado.

season (approximately April to October) (fig. 17). The gaging station was originally (2004) located on the right bank with the ADVM mounted on an adjustable frame driven into the canal bed at the gage. During the non-irrigation season, the gage was moved to a different location at the downstream right bank edge of a bridge over the canal for 2005. The ADVM was mounted on a 2-in. pipe at the right bank of the Redlands Canal. The sampling volume began at $5 \mathrm{ft}$ and ended at $30 \mathrm{ft}$ (2004) or $20 \mathrm{ft}$ (2005) out from the transducer with 5 -ft cell lengths.

\section{Hydrology and Streamflow Conditions}

The Redlands Canal was mostly at normal capacity during the season of operation; discharge did not vary to a great extent (fig. 17). The canal channel was the gageheight control near the ADVM and stream gage. The water surface at the gage was smooth, and the water was turbid. The velocity distribution across the channel was fairly uniform based on acoustic Doppler current profiler (ADCP) measurements.

\section{Comparison of Velocity-Index and Stage/ Discharge Computations}

The computation of ADVM discharge record at Redlands Canal required two velocity-index ratings, one for July to October 2004 (rating 1) and one for April to August 2005 (rating 2). The ADVM velocity record was complete for the period of deployment in water years 2004 and 2005. The quality of the velocity data was assessed by examining graphs and by examining the discharge hydrograph produced from the velocity data. The index-velocity relation for this site is based on instrument velocity and discharge-measurement velocity. The average of all cells was used as the ADVM instrument velocity because the average had a better correlation with the ADVM velocity than any one individual cell (fig. 18). Two ratings (fig. 18) were needed because the gage was moved in April 2005. Rating 1 (2004 site) had an adjusted coefficient of determination $\left(\mathrm{r}^{2}\right)$, standard error, and standard error as a percentage of the mean velocity of the measured discharge, 0.984, $0.024 \mathrm{ft} / \mathrm{s}$, and 1.1 percent, respectively. Rating 2 (2005 site) had an adjusted coefficient of determination $\left(\mathrm{r}^{2}\right)$, standard 


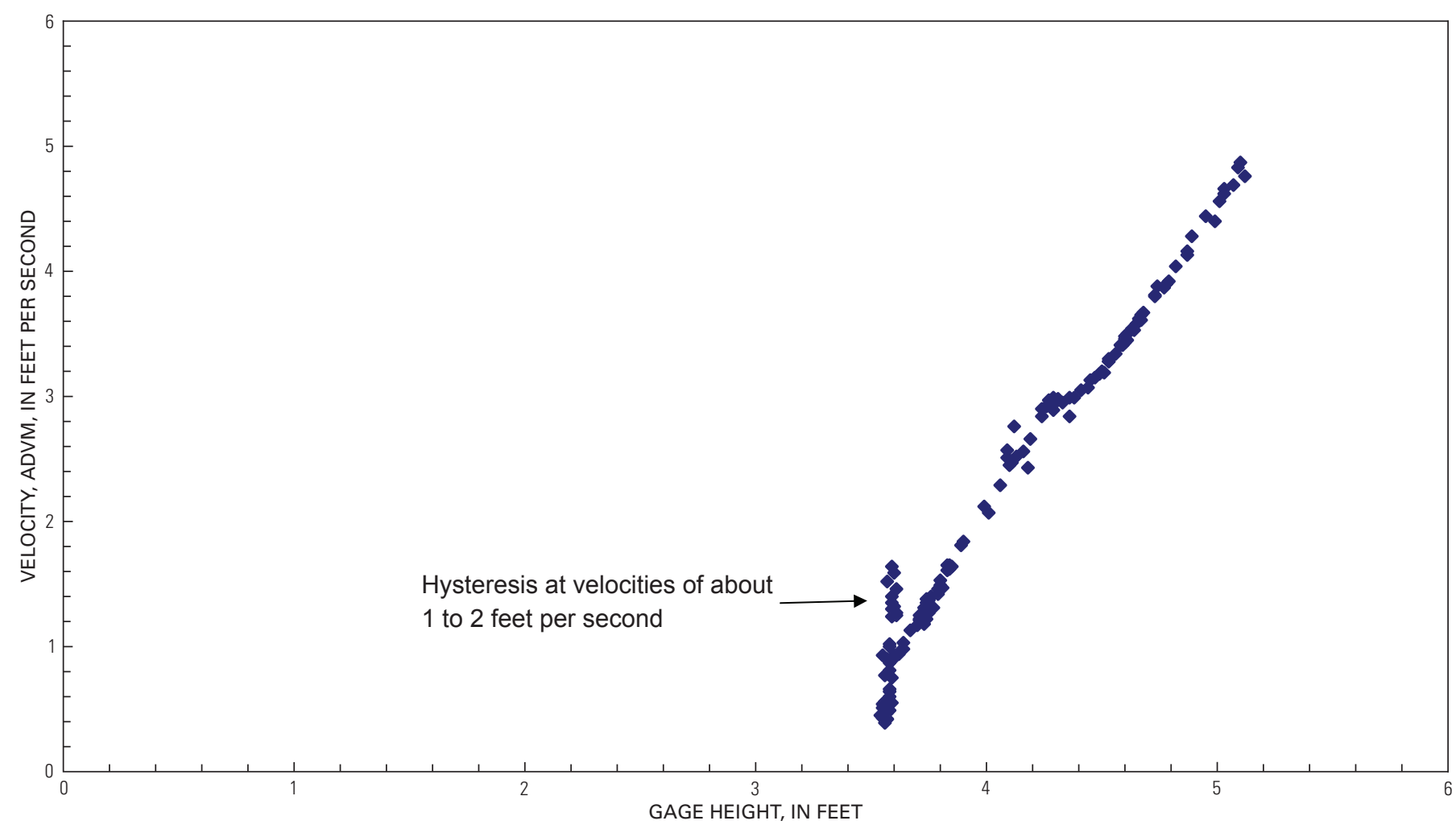

Figure 13. Acoustic Doppler velocity meter (ADVM) velocity and gage-height values at Clear Creek above West Fork Clear Creek, near Empire, Colorado, mid-July through August 2005, indicating hysteresis at velocities of about 1 to 2 feet per second.

error, and standard error as a percentage of the mean velocity of the measured discharge, $0.986,0.034 \mathrm{ft} / \mathrm{s}$, and 1.0 percent, respectively. The $\mathrm{r}^{2}$ values indicated a good linear relation. For rating 1 the percent difference between the velocity derived from instantaneous discharge measurements and those derived from the ADVM ranged from -1.87 to 1.54 percent. For rating 2 , the percentage of difference between the velocity derived from instantaneous discharge measurements and those derived from the ADVM ranged from -3.02 to 0.86 percent. The percent differences were considered to have acceptable rated measurement error (less than 5 percent is rated good). Thus, no shifts to the velocity-index rating were necessary at this site.

The Redlands Canal stage/discharge ratings were developed using ADCP measurements of discharge. Stage shifts based on discharge measurements during the year were applied (shift analysis by USGS). Stage record was provided by the DWR and corrections of the gage-height record to base gage were minimal. The stage record was complete. No estimates for missing or ice-affected record were made. Discharge data for 8 days were unreliable primarily because equipment malfunctioned; these data were not used for comparison.

\section{Evaluation of ADVM Performance at Redlands Canal}

In general, the ADVM discharge compared well to computed discharge daily values (figs. 19-21). Most of the
2004 percent differences in daily mean values ranged from about negative 1 to negative 6 percent (fig. 20). In 2005, at the new location, percent differences in daily mean values ranged from about 0 to about positive 2 percent and a maximum near 3 percent (fig. 20). No major problems were encountered.

However, discharge measurements (used to compute measured velocity) were difficult to obtain over a range in stage because the Redlands Canal is usually operated at near-full capacity at all times. The operator of the diversion assisted by varying the discharge in the canal so a range of measurements could be made (about 700 to $850 \mathrm{ft}^{3} / \mathrm{s}$ ).

\section{Conclusions}

ADVM instrumentation and discharge computation were successful and compared favorably, generally within 5 to 10 percent, with the stage/discharge method at three Colorado test locations. ADVMs have been used extensively in other regions of the country by the USGS, being indispensable for tidal streams, backwater-influenced gages, and canals with lock-and-dam flow reversals, for multiple adjustable headgates influencing stage at a gage location, and for routine gaging purposes. However, Colorado's shallow, clear, coarse-bed streams that freeze in winter may impose additional challenges for effective use of ADVM technology. 


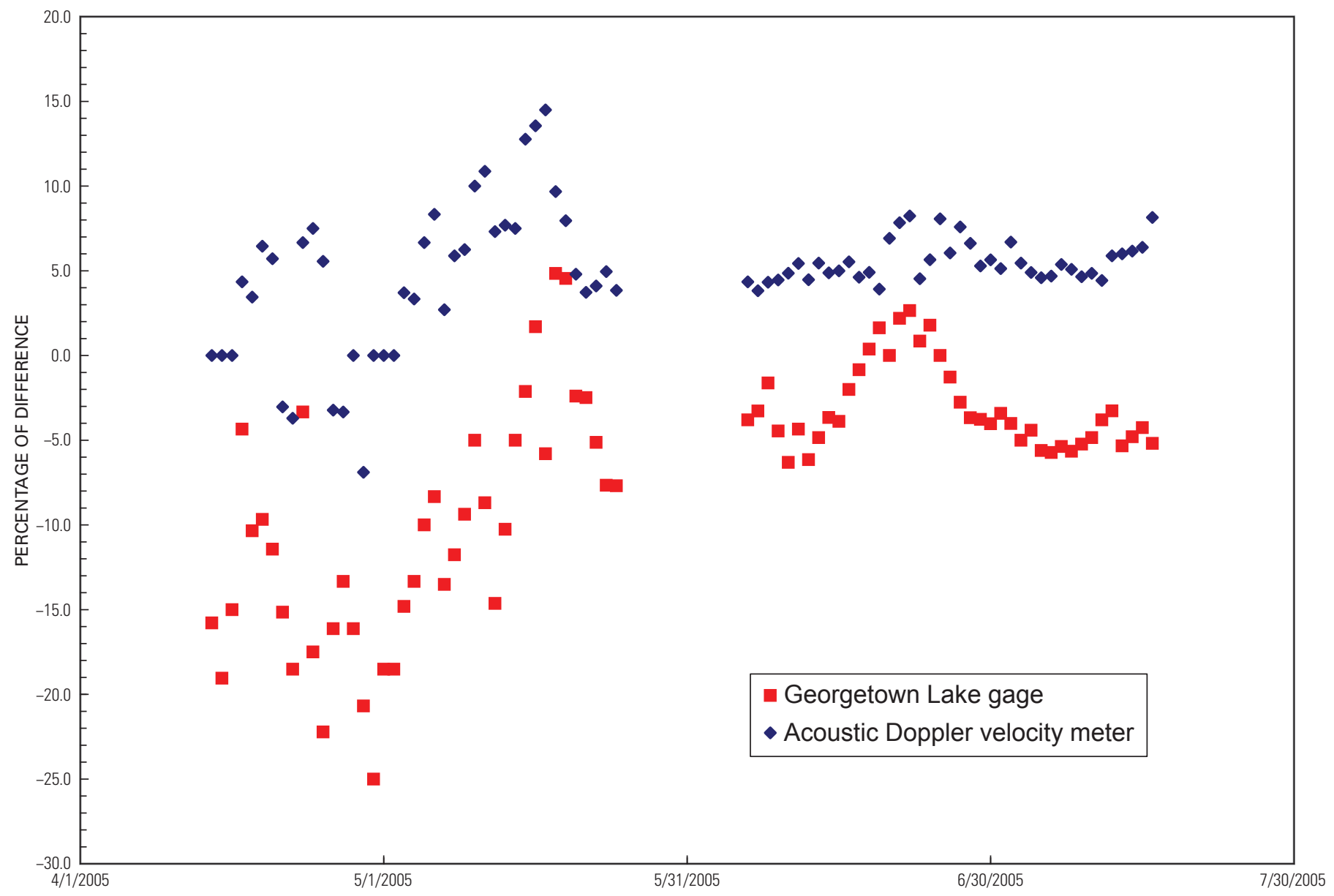

Figure 14. Percentage of difference between daily mean discharge determined by acoustic Doppler velocity meter (ADVM) and those computed by the stage/discharge relation at Clear Creek above West Fork Clear Creek, near Empire, Colorado, and the percentage of difference between daily mean discharge computed by stage/discharge relation at Clear Creek above Georgetown Lake and the daily mean discharge computed by stage/discharge relation at Clear Creek above West Fork Clear Creek, near Empire, Colorado.

To be successful, the preparation of velocity-index ratings, collection of accurate stage record, and current-meter or ADCP discharge measurements are required. Currently (2006), the ADVM instrumentation costs are more than double the costs for a typical small stilling well or pressure transducer and basic data recorder. Because the optional uplooking transducer for stage measurement for the ADVM has not yet met USGS standards for $0.01-\mathrm{ft}$ stage precision, additional stage-measurement equipment may be necessary for the full instrument setup. The entire ADVM instrument is installed in the stream, which could make it vulnerable to vandalism or damage from ice or debris at some locations. Some users have built metal boxes, open at one end for the transducer beams, to protect the ADVM.

The instrument data can be logged by the ADVM, or sent to existing loggers or to telemetry equipment for near-realtime data. Sites with simple hydraulics and single, trapezoidal channels (like those in this study) should produce simple linear velocity-index ratings that can be implemented as an equation to compute mean velocity from ADVM velocity data. Variable shifting (stage and time) is not easily done (time-shifts allowed only) with the current version (2006) of USGS Automated Data Processing System (ADAPS), but shifting should not be necessary unless the channel geometry or hydraulics change in the area-reference cross section or ADVM cross section, which are often the same. A shifting control is not problematic as long as the ADVM section and hydraulics are stable.

Several potential problems with ADVM are perhaps more prevalent in the arid, cold, Rocky Mountain West. First, low-flow season is often accompanied by acutely shallow depths (less 2-3 ft) in many Colorado streams. The sidelooking ADVM used in shallow water requires short blanking distance and relatively short cell lengths (such as Clear Creek with about $1.5 \mathrm{ft}$ blanking distance and a $3 \mathrm{ft}$ first cell). The ADVM should be installed fairly close to the centroid of flow so that sufficient depth is maintained from the instrument to the centroid (a good hydraulic location for ADVM in rocky or shallow streams). For some streams, the practical depth required for a side-looking ADVM (approximately $1.5 \mathrm{ft}$ ) cannot be met at all times of the year. Second, cold temperatures 


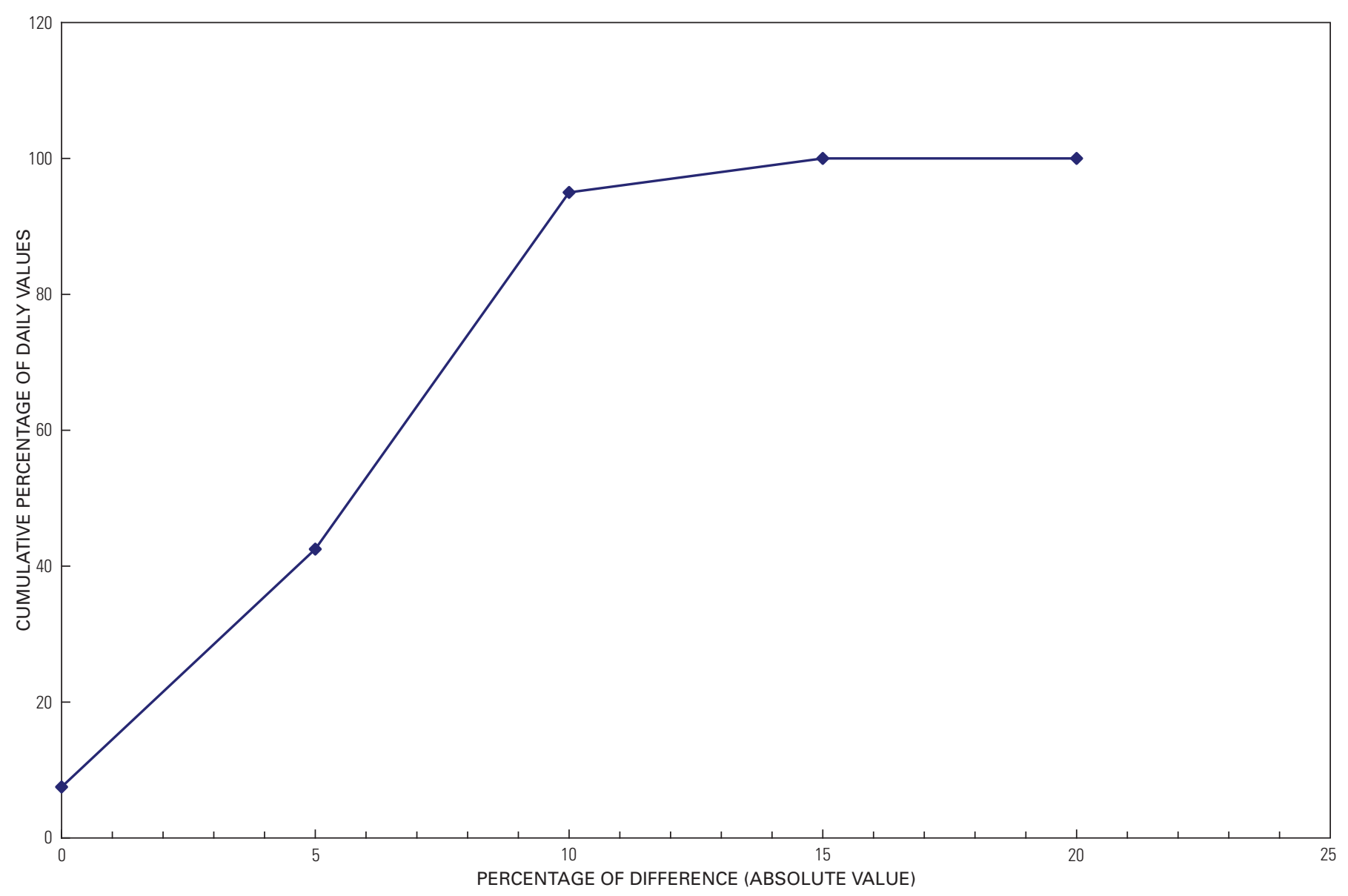

Figure 15. Cumulative percentage of absolute difference compared to absolute percentage of difference between acoustic Doppler velocity meter (ADVM) and computed discharge, Clear Creek above West Fork Clear Creek, near Empire, Colorado.

and sometimes freezing-thawing cycles can produce ice effects that could prevent collection of reliable ADVM (and stage) data. Under-ice methods for ADVM are being studied by the USGS in North Dakota (Lambrecht, 2004), but Colorado's shallow waters may be problematic for under-ice operations.

Some Colorado streams have conditions where measurements may be enhanced in terms of accuracy or ease of computation by implementing ADVM instrumentation. Variable backwater from tributary inflow, beaver dams, ice effect, diversion dams, canal operations, or debris is a problem for conventional stage/discharge computations but can be handled by ADVM by including stage as a variable in the indexvelocity equation. This technique allows for more than one discharge at a given gage height. Wide, low-gradient reaches can result in imprecise discharge computations because of the flat slope of the stage/discharge relation. The ADVM index-velocity slope may be more sensitive than stage and can even use the changes in velocity and stage to strengthen the rating relation. Low-flow conditions can be difficult at some sites due to the propensity of small changes in the control to cause variable shifting of the rating. Although the side-looking ADVM instrument used in this study has a fairly substantial water-depth requirement (by small-stream standards), some ADVM instruments made for shallow water are mounted on the streambed and look upward through the water column and can operate in water as shallow as $0.5 \mathrm{ft}$. These bottom-mounted instruments have not been verified by the U.S. Geological Survey (Sontek, 2005, http://www. sontek.com/product/asw/aswov.htm). However, the effect of large-particle bedload transport could effect the operation and structural integrity of the bottom-mounted instrument in certain locations. Some sites affected by flow reversals or bidirectional flows would also benefit from the ADVM capability to measure velocity in reversing conditions and to integrate flow directions in a single cross section. As mentioned previously, some users have had success at measuring flow under the ice by using the ADVM velocity and some measure of depth of flow under ice (an upward-looking transducer may provide useful estimates). This might also be an application for the up-looking, bottom-mounted, shallowwater ADVM described previously. Another advantage to ADVM is that, because a stage record also must be collected, stage/discharge also can be computed to verify or substitute for periods of questionable ADVM record. 
FileName: DEFC2004.arg (Argonaut- SL $1500 \mathrm{kHz}$ )

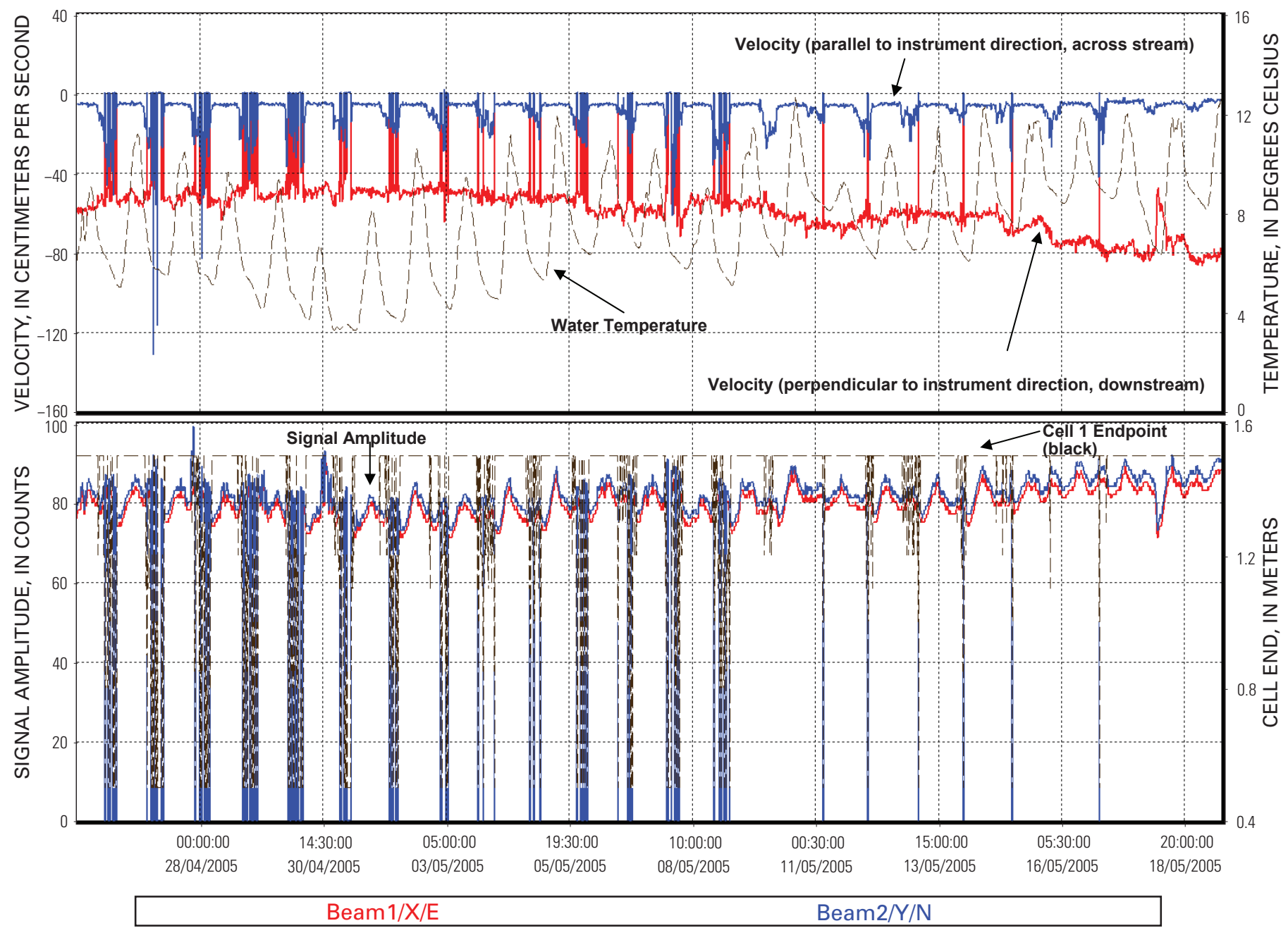

Figure 16. Response of the acoustic Doppler velocity meter to runoff conditions April 27 to May 19, 2005, Clear Creek above West Fork Clear Creek, near Empire, Colorado.

The ADVM used in this study, the Argonaut-SL 1500 $\mathrm{kHz}$ instrument, has a manufacturer-published accuracy of 1 percent of the velocity or $0.015 \mathrm{ft} / \mathrm{s}$, which has not been verified by the USGS. Much of the ADVM discharge computed for this study was within 5 percent of the stage/discharge except at Clear Creek. The Clear Creek record was rated good for the 2005 water year. Most of the differences involved between ADVM discharge and USGS conventional stage/ discharge are within combined error margins of the two methods at the three sites evaluated in this study. It is difficult to know whether the ADVM or the stage/discharge record should be the standard of comparison given uncertainties associated with both methods. The accuracy of stage/discharge records in Colorado is qualified with a statement in the USGS 2004 annual data report for Colorado.

\begin{abstract}
"The degree of accuracy of the records is stated in the REMARKS in the station description. "Excellent" indicates that about 95 percent of the daily discharges are within 5 percent of the true value; "good" within 10 percent; and "fair," within 15 percent. "Poor" indicates that daily discharges have less than "fair" accuracy. Different accuracies may be attributed to different parts of a given record" (Crowfoot and others, 2005).
\end{abstract}

Colorado hydrologic settings may offer fewer compelling situations for using the ADVM instruments described in this report than many other parts of the United States, especially if less expensive alternatives for seasonal gage operations are available. ADVM can be considered a useful option for data collection for discharge computations in Colorado streams. 


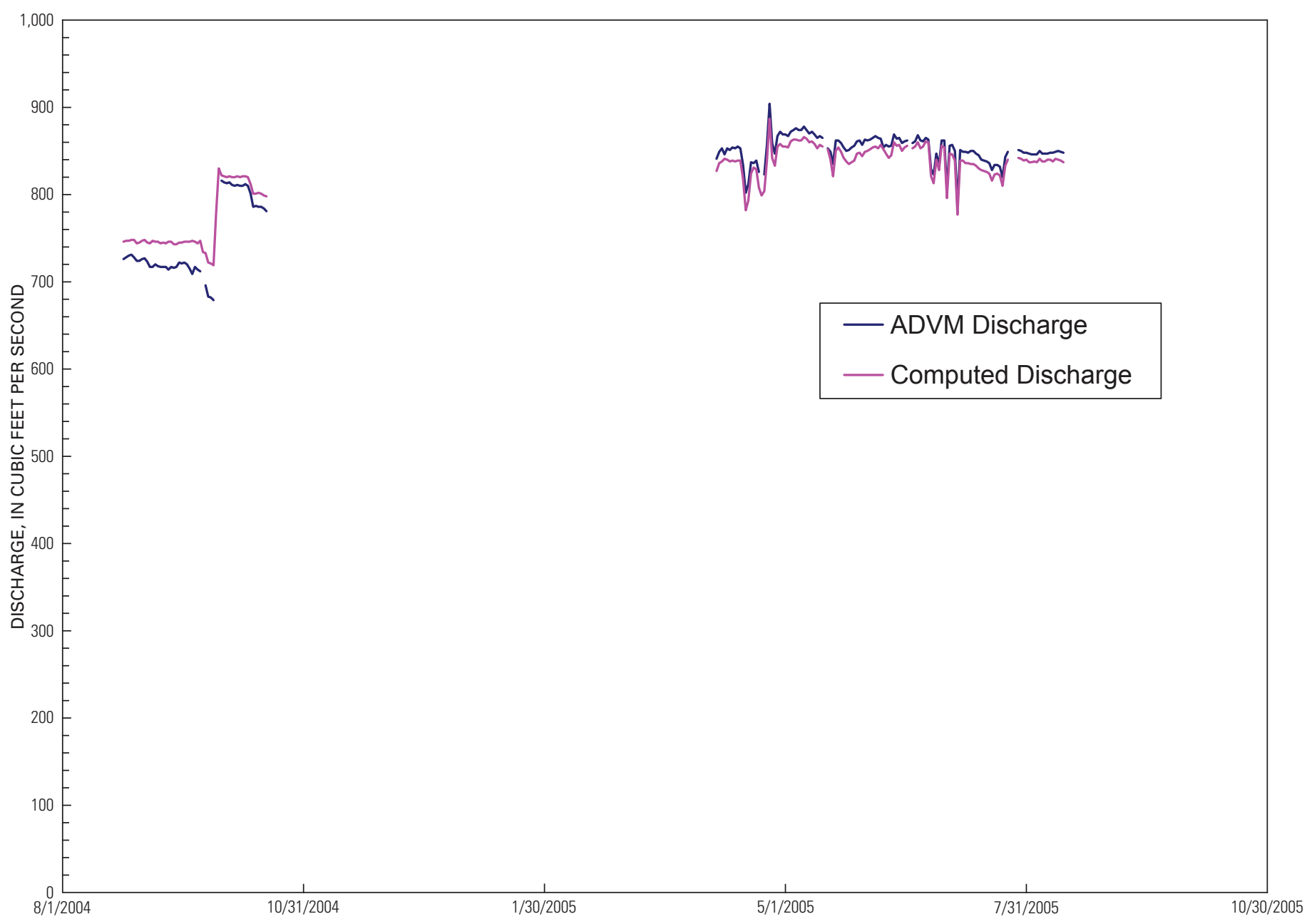

Figure 17. Comparison of mean daily discharge produced by conventional methods (computed) and by acoustic Doppler velocity meter (ADVM), Redlands Canal near Grand Junction, Colorado. Breaks in the graphs represent periods of no data.

\section{Summary}

Acoustic Doppler velocity meter (ADVM) technology was tested and evaluated at three sites in Colorado with different hydrologic settings for the purpose of evaluating ADVM-discharge data and instrument performance compared to conventional stage/discharge data. These sites were Bear Creek at Morrison, Clear Creek above West Fork Clear Creek near Empire, and Redlands Canal near Grand Junction. The sites were selected based on the following criteria: existing streamflow-gaging stations; sufficient water depth; reference section stability; the safety and security of the instrument; input from Colorado Water Conservation Board, Colorado Division of Water Resources, and the U.S. Geological Survey; and for their differing hydrologic and hydraulic characteristics. The Bear Creek site was selected primarily for a stable stage/ discharge control structure; deep, stable pool; and restricted access (security). The Clear Creek site was selected primarily because it is a natural channel and similar to many mountain gage sites in the U.S. Geological Survey and Colorado Division of Water Resources networks. The Redlands Canal site was selected because it had a stage/discharge relation that has exhibited some degree of uncertainty, it is a site that represents manmade conveyances (a typical ADVM site implementation), and the site was of interest to the Colorado Division of Water Resources. Streamflow records were computed at each site using the conventional stage/discharge rating methods and index-velocity methods. Comparisons were made between the stage/discharge and velocity-index (ADVM) methods in order to determine the feasibility, advantages, problems, and potential opportunities to use ADVM technology.

In general, at the Bear Creek site, the ADVM discharge data compared well to conventional stage discharge. Most of the percent differences in daily mean values ranged from positive and negative 5 percent and a maximum of 15 percent. At the upper end of the discharge range (above $150 \mathrm{ft}^{3} / \mathrm{s}$ ) the ADVM tended to under predict discharge compared to the stage discharge. This result could be due to the lack of definition of the shift at the upper end of the stage/discharge rating or because of the extension of the velocity index rating above the highest measurement with the ADVM in place. Ice was a problem at this site; it affected the velocity data so that little 


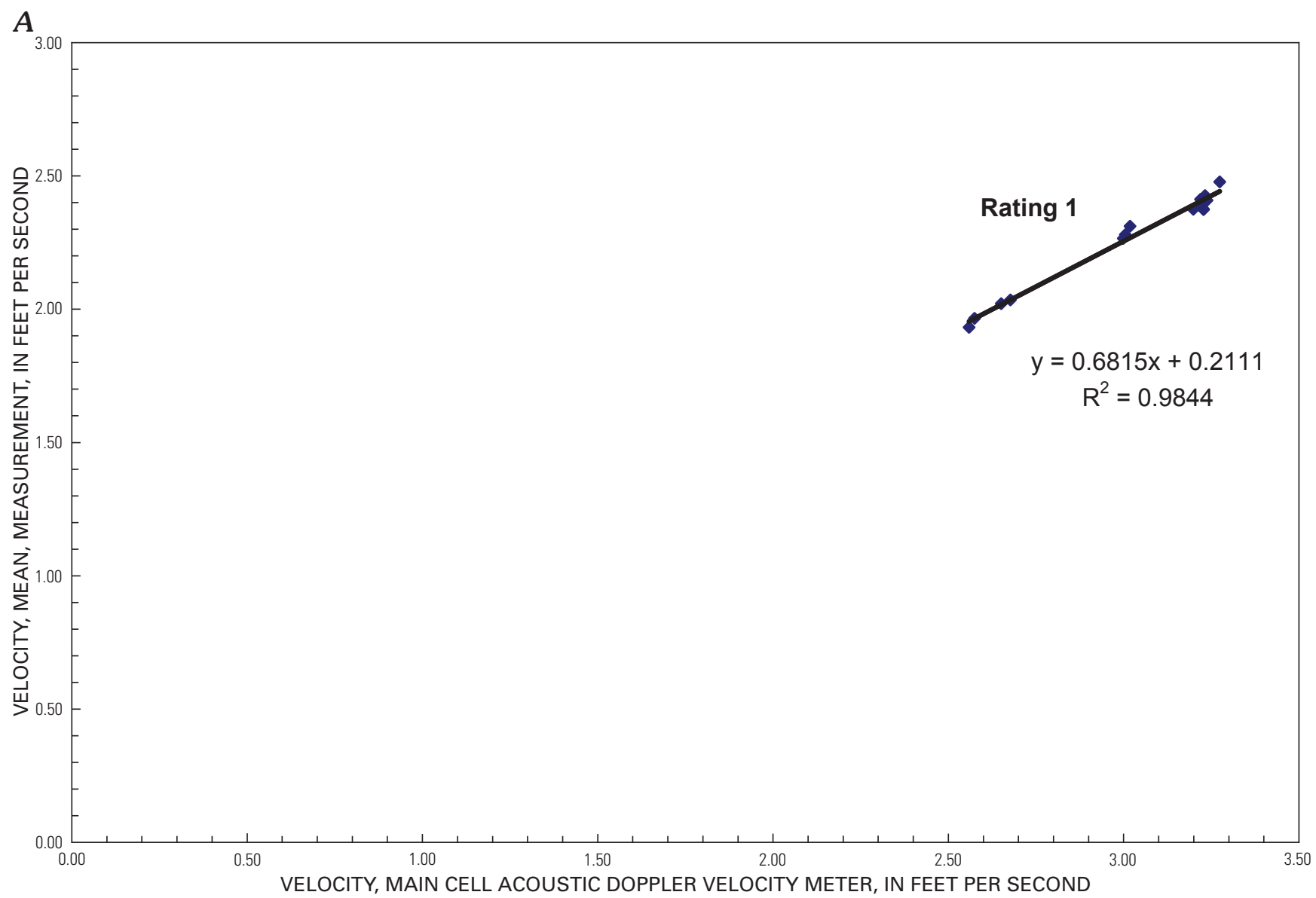

$B$

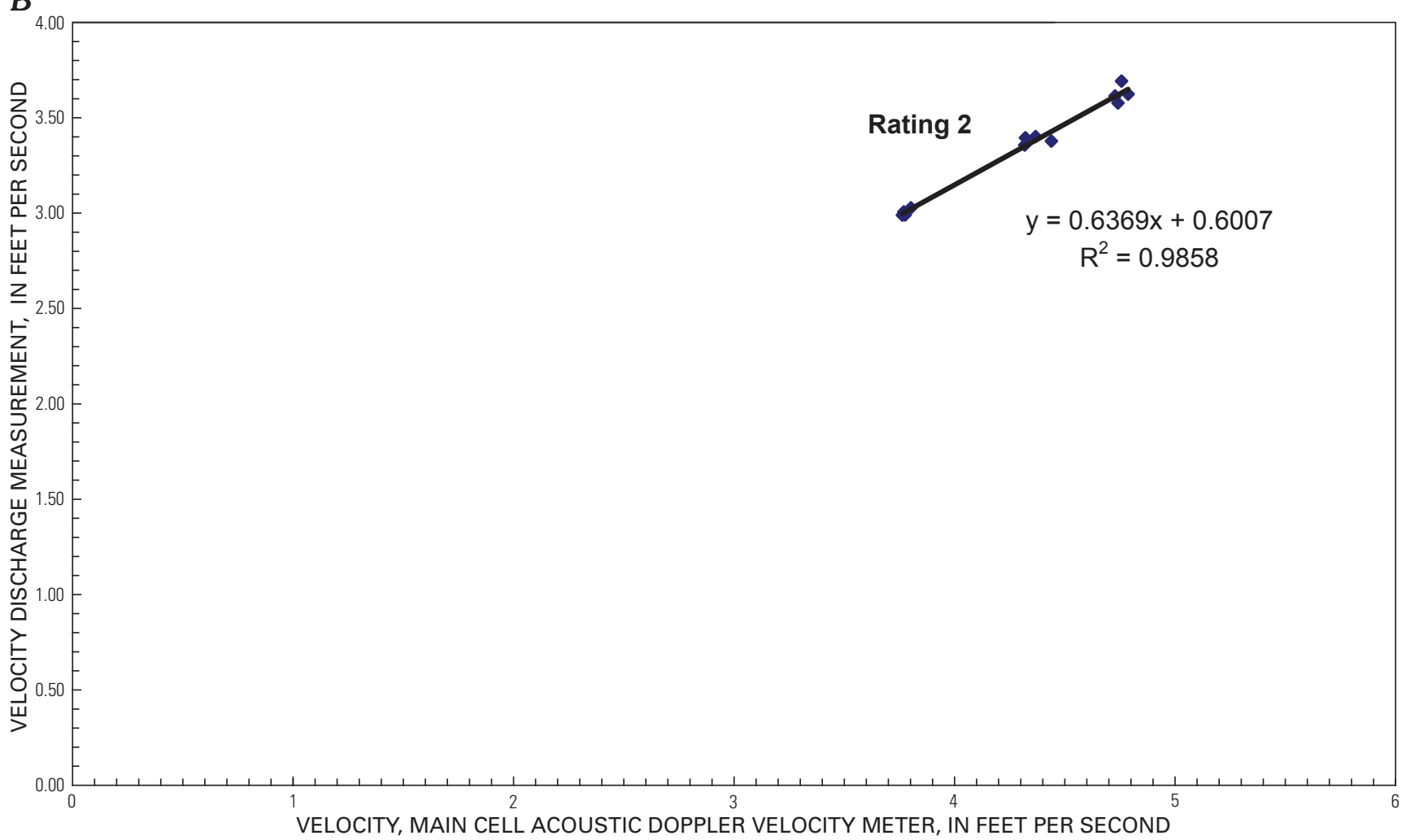

Figure 18. Velocity-index ratings for Redlands Canal near Grand Junction, Colorado: (A) rating 1, velocities measured 2004, and (B) rating 2, velocities measured 2005. 


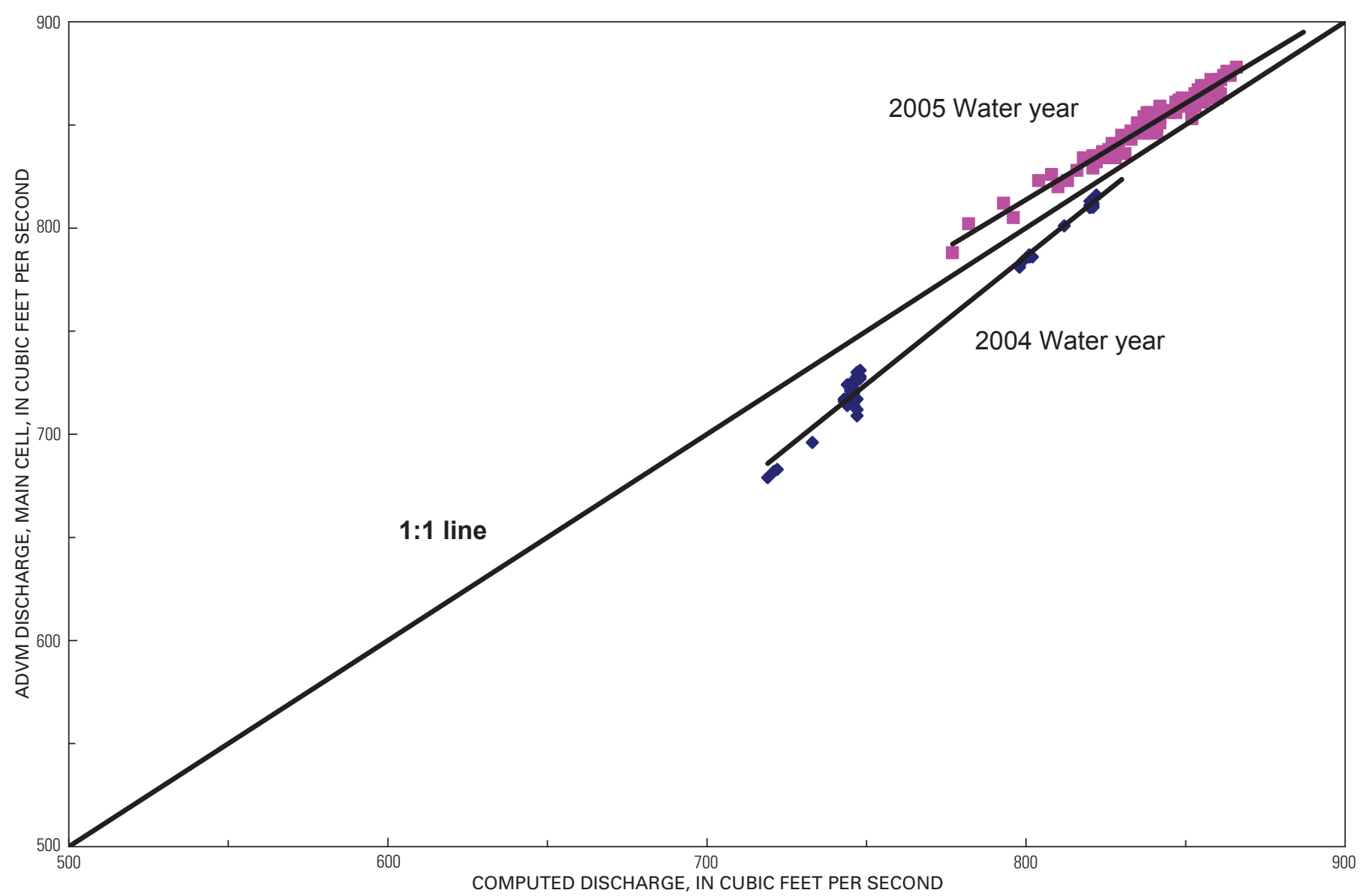

Figure 19. Comparison of computed and acoustic Doppler velocity meter (ADVM) discharge, Redlands Canal near Grand Junction, Colorado.

useful ADVM record was obtained when the water temperatures dropped to $0^{\circ} \mathrm{C}$. Bear Creek is shallow, subject to midwinter thaws and ice breakups, partial ice cover, frazil ice, and anchor ice. The characteristics of ice formation likely affected the ADVM and velocity data.

In general, at the Clear Creek site, the ADVM discharge data compared more unfavorably to conventional stage discharge than at Bear Creek. Most of the percent differences in daily mean values ranged from positive 10 to negative 5 percent and a maximum of approximately 20 percent. The patterns in the percent differences with time are thought to be a result of site-specific influences on the stage-discharge record at the Clear Creek site and seem to be independent of the ADVM. This pattern could be a result of short-term shifts in the control that were not accounted for by the discharge measurements. Because the ADVM is not affected by changes in the control, the ADVM discharge might be more reliable in some instances. The ADVM at Clear Creek seemed to have been affected by cold weather, causing a low bias in velocity and discharge, and an unexplained periodic increase in noise levels, causing decreases in signal amplitude (backscatter) and signal-to-noise ratio, and adjustment of cell endpoints.
In general, at the Redlands Canal site, the ADVM discharge data compared best to conventional stage-discharge daily values relative to the Bear Creek and Clear Creek sites. Most of the 2004 percent differences in daily mean values ranged from negative 1 to negative 6 percent. In 2005, at the new location, percent differences in daily mean values ranged from zero to positive 2 percent and a maximum near 3 percent.

Some Colorado streamflow-gaging sites have conditions where ADVM measurements may enhance accuracy or ease of computation. Variable backwater from tributary inflow, beaver dams, ice effect, diversion dams, canal operations, or debris are problematic for stage/discharge records, but can be handled by ADVM methods using stage as a variable in the index-velocity equation if necessary. This technique allows for more than one discharge at a given gage height and can reduce or eliminate the need for shift correction for changes in the control.

Colorado hydrologic settings may offer fewer compelling situations for using the ADVM instruments described in this report than many other parts of the United States, especially if less expensive alternatives for seasonal gage operations are available. ADVM can be considered a useful option for data collection for discharge computations in Colorado streams. 


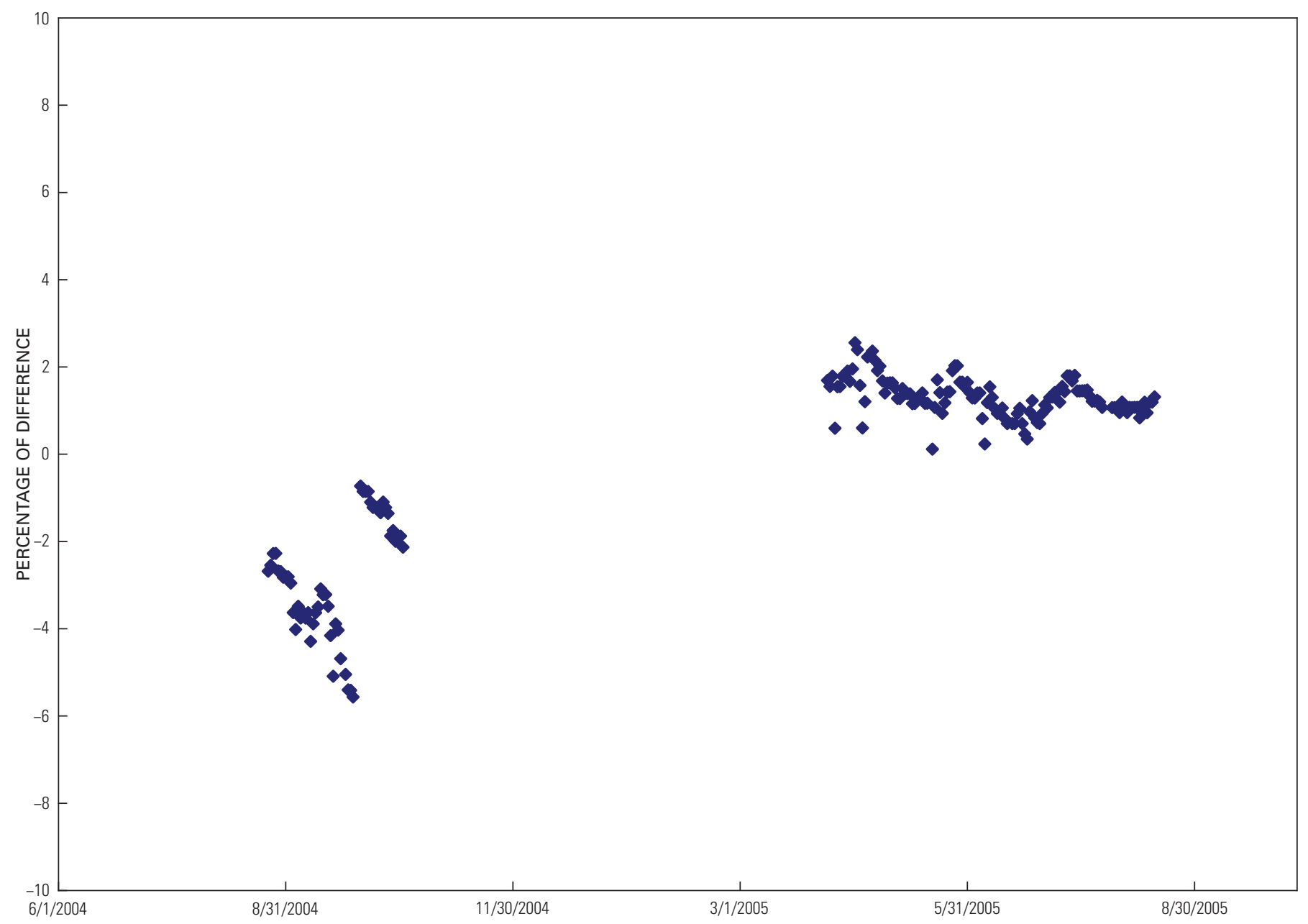

Figure 20. Percentage of difference between daily mean discharge determined by acoustic Doppler velocity meter and those computed by the stage/discharge relation, Redlands Canal near Grand Junction, Colorado. 


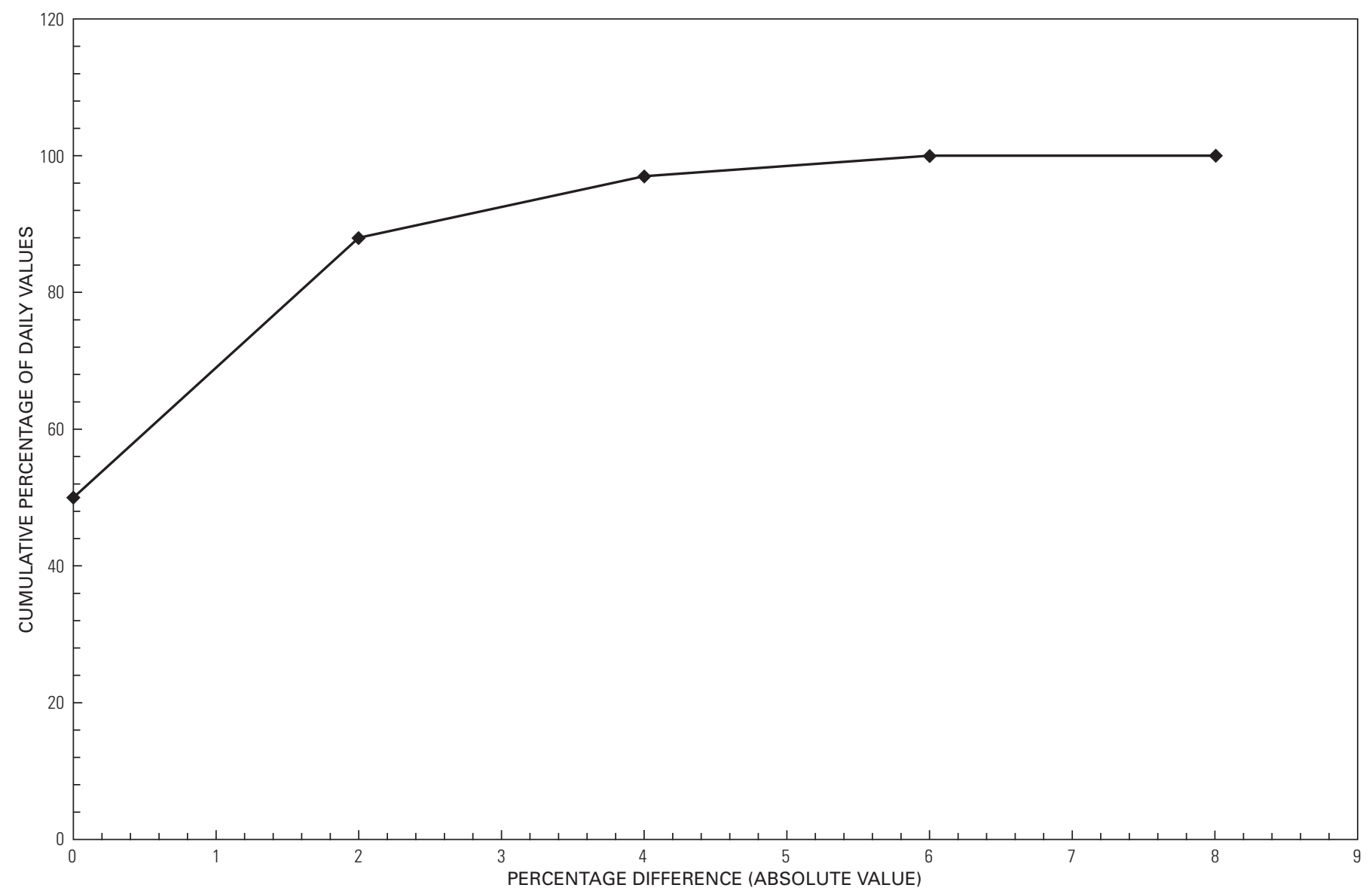

Figure 21. Cumulative percentage of absolute difference compared to absolute percentage of difference between acoustic Doppler velocity meter (ADVM) and computed discharge, Redlands Canal near Grand Junction, Colorado.

\section{Acknowledgments}

The authors thank Jeffrey Baessler of the CWCB and the CWCB for their interest in testing alternative hydrologic instrumentation in Colorado. Thanks also to Jerry Thrush, Steve Barrett, and Bob Cooper of the Colorado Division of Water Resources (DWR) for their expertise and data-collection support at gaging stations operated by the DWR. Thanks also to Barbara C. Ruddy for technical assistance with preparation of the manuscript.

\section{References Cited}

Buchanan, T.J. and Somers, W.P., 1969, Discharge measurements at gaging stations: U.S. Geological Survey Techniques of Water-Resources Investigations, book 3, chap. A8, 65 p.

Burgi, P.H., and Johnson, P.L., 1971, Ice formation-A review of the literature and Bureau of Reclamation experience: Bureau of Reclamation Report REC-ERC_-71-8, 26 p.
Crowfoot, R.M., Payne, W.F., O’Neill, G.B., Boulger, R.W., 2005, Water resources data, Colorado, water year 2004: U.S. Geological Survey Water-Data Report WDR-CO_04-1, 408 p.

Doesken, N. J., McKee, T. B., and Richter, Brian, 1984, Analysis of Colorado average annual precipitation for the 1951-1970 period, Climate Report 84-4: Department of Atmospheric Science, Colorado State University, Fort Collins, CO, December, 53 p.

Hoyt, W.G., 1913, The effects of ice on streamflow: U.S. Geological Survey Water-Supply Paper 337, 77 p.

Kennedy, E.J., 1983, Computation of continuous records of streamflow: U.S. Geological Survey Techniques of WaterResources Investigations, book 3, chap. A13, 53 p.

Kuhn, Gerhard, and Williams, C.A., 2004, Evaluation of streamflow losses along the Gunnison River from Whitewater downstream to the Redlands Canal diversion dam, near Grand Junction, Colorado, water years 1995-2003: U.S. Geological Survey Scientific Investigations Report 2004-5095, 22 p. 
Lambrecht, J.M., 2004, Measurement of discharge using acoustics at the Red River of the North at Grand Forks, North Dakota: Presentation by U.S. Geological Survey personnel at the Hydroacoustics Workshop 2004, San Diego, Calif., March 22-26, 2004.

Melcher, N.B., and Walker, J.F., 1992, Evaluation of selected methods for determining streamflow during periods of ice effect: U.S. Geological Survey Water-Supply Paper 2378, 47 p.

Morlock, S.E., Nguyen, H.T., and Ross, J.H., 2002, Feasibility of acoustic doppler velocity meters for the production of discharge records from U.S. Geological Survey streamflow gaging stations: U.S. Geological Survey Water-Resources Investigations Report 2001-4157, 56 p.

Oberg, K.A., Morlock, S.E., and Caldwell, W.S., 2005, Quality assurance plan for discharge measurements using acoustic Doppler current profilers: U.S. Geological Survey Scientific Investigations Report 2005-5183, 35 p.

Rantz, S.E., and others, 1982, Measurement and computation of streamflow: U.S. Geological Survey Water-Supply Paper 2175, 2 v., 631 p.

Rehmel, M.S., Stewart, J.A., and Morlock, S.E., 2003, Tethered acoustic Doppler current profiler platforms for measuring streamflow: U.S. Geological Survey Open-File Report 2003-237, 15 p.

Ruhl, C.A., and Simpson, M.R., 2005, Computation of discharge using the index-velocity method in tidally affected areas: U.S. Geological Survey Scientific Investigations Report 2005-5004, 31 p.

Simpson, M.R., 2001, Discharge measurements using a broadband acoustic Doppler current profiler: U.S. Geological Survey Open-File Report 2001-1, 123 p.

Sontek, 2001, Technical documentation-Sontek Argonaut acoustic Doppler current meter: San Diego, Calif., variously paginated.

Stevens, M.R., 2001, Assessment of water quality, road runoff, and bulk atmospheric deposition, Guanella Pass area, Clear Creek and Park Counties, Colorado, water years 1995-97: U.S. Geological Survey Water-Resources Investigations Report 2000-4186, 183 p.

U.S. Geological Survey, 2003, Users manual for the national water information system of the U.S. Geological SurveyAutomated data processing system (ADAPS): U.S. Geological Survey Open-File Report 2003-123 version 4.3, 407 p. http://pubs.usgs.gov/of/2003/ofr03123

U.S. Geological Survey Office of Surface Water, 2002a, Configuration of acoustic profilers (RD Instruments) for measurement of streamflow: OSW Technical Memo 2002.01, 6 p. http://water.usgs.gov/admin/memo/SW/
U.S. Geological Survey Office of Surface Water, 2002b, Policy and technical guidance on discharge measurements using acoustic Doppler current profilers: OSW Technical Memo 2002.02, 4 p. http://water.usgs.gov/admin/memo/SW/

Wang, Dapei, 2004, Channel discharge computation with AVM data: Presentation at Hydroacoustics Workshop 2004, San Diego, Calif., March 22-26, 2004.

Publishing support provided by:

Denver Publishing Service Center, Denver, Colorado Manuscript approved for publication, October 2007 Edited by Mary Kidd

Layout by Mari Kauffmann (Contractor, ATA Services) 


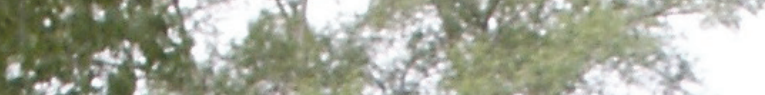

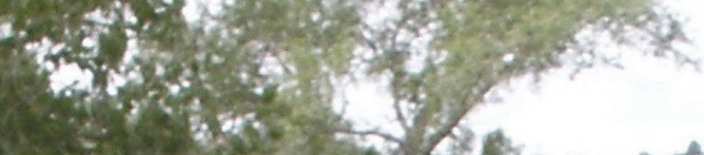

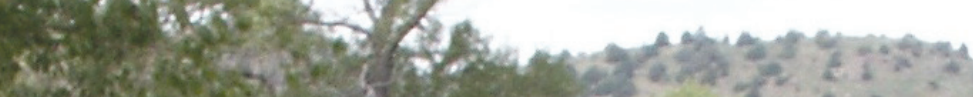
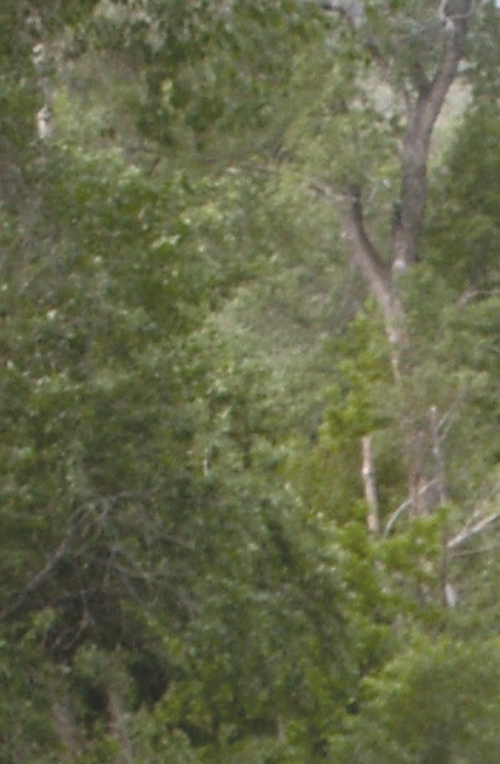

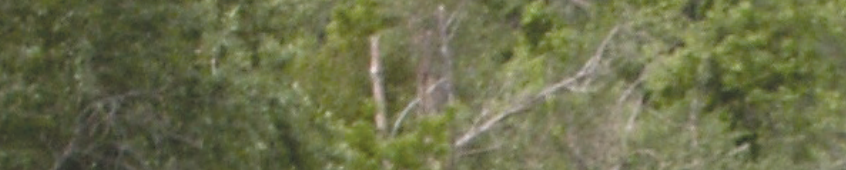

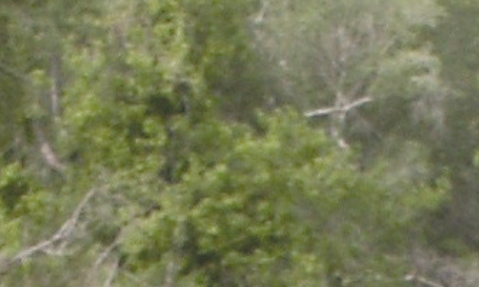

